University of Michigan Law School

University of Michigan Law School Scholarship Repository

Articles

Faculty Scholarship

2002

\title{
Property in Writing, Property on the Ground: Pigs, Horses, Land, and Citizenship in the Aftermath of Slavery, Cuba, 1880-1909
}

Rebecca J. Scott

University of Michigan Law School, rjscott@umich.edu

Michael Zeuske

Universität zu Köln, mzeus@web.de

Available at: https://repository.law.umich.edu/articles/796

Follow this and additional works at: https://repository.law.umich.edu/articles

Part of the Civil Rights and Discrimination Commons, Law and Race Commons, Legal History Commons, and the Property Law and Real Estate Commons

\section{Recommended Citation}

Scott, Rebecca J., co-author. "Property in Writing, Property on the Ground: Pigs, Horses, Land, and Citizenship in the Aftermath of Slavery, Cuba, 1880-1909." M. Zeuske, co-author. Comp. Stud. Soc'y \& Hist. 44, no. 4 (2002): 669-99.

This Article is brought to you for free and open access by the Faculty Scholarship at University of Michigan Law School Scholarship Repository. It has been accepted for inclusion in Articles by an authorized administrator of University of Michigan Law School Scholarship Repository. For more information, please contact mlaw.repository@umich.edu. 


\title{
Property in Writing, \\ Property on the Ground:
}

\section{Pigs, Horses, Land, and Citizenship in the Aftermath of Slavery, Cuba, 1880-1909}

\author{
REBECCA J. SCOTT \\ University of Michigan \\ MICHAEL ZEUSKE
}

Universität zu Köln

In the most literal sense, the abolition of slavery marks the moment when one human being cannot be held as property by another human being, for it ends the juridical conceit of a "person with a price." At the same time, the aftermath of emancipation forcibly reminds us that property as a concept rests on relations among human beings, not just between people and things. The end of slavery finds former masters losing possession of persons, and former slaves acquiring it. But it also finds other resources being claimed and contested, including land,

Rebecca Scott would like to thank David Brion Davis, Sidney Mintz and Brian Pollitt for discussions on slavery and peasantries, and Sara Berry, Hanoch Dagan, Gillian Feeley-Harnick, Bruce Frier, Robert Gordon, Tom Green, Hendrik Hartog, Michael Heller, Ellen Katz, James Krier, Richard Pildes, Stuart Schwartz, Katherine Verdery, and especially Carol Rose for sharing their work and thoughts on property. Michael Zeuske would like to thank Ovidio Cosme Díaz Benítez for collaboration in document analysis, and Grisel Ramos Maceda for assistance in the work of transcription. Both of us thank Sharad Chari, John Dumoulin, Leida Fernández, Josep María Fradera, Alejandro García, Ramón Garrabou, Juan Giusti, Marial Iglesias, Steven Jacobson, Fernando Martínez Heredia, Jesús Millán, Dylan Penningroth, Reinaldo Román, Richard Turits, and three anonymous $\mathrm{CSSH}$ reviewers for advice and probing questions. We have built upon conversations with many residents of rural Cienfuegos, including Evelio Castillo and Tomás Pérez y Pérez, whose recent deaths we mourn. We owe special thanks to their kin and neighbors Araceli Quesada y Quesada, Caridad Quesada, Ramona Quesada de Castillo, Gerardo Quesada, Francisco Quesada, Humberto Quesada, Francisco Mena Aguila, Eduardo Girón, Lidia Girón, Lenny Sarría, Marcelino Iznaga Suárez Román, Manuel Muñoz Soriano, Arturo Iznaga and family, Fermín Tellería, Félix Tellería, and Leonardo Alomá. Both authors are very grateful to Orlando García Martínez, director of the Provincial Archive of Cienfuegos, and to the staff of that archive. García is also the coordinator of the project "Rescate de la Memoria Viva," within which we carried out these interviews. The staff of the Massachusetts Historical Society, and particularly its librarian, Peter Drummey,

0010-4175/02/669-699 \$9.50 C 2002 Society for Comparative Study of Society and History 
tools, and animals - resources that have shaped former slaves' working lives to date, and that now shape their prospects for the future. When former slaves make claims to such resources, they may draw on an idea of customary possession, or they may assert rights to respect and remuneration. The resulting conflicts thrust into the open the links between freedom, property, and membership in the political community. ${ }^{1}$

Gradual slave emancipation in Cuba (1868-1886) took place during a period of intense competition for popular loyalty between the Spanish colonial state and Cuban separatists. Maneuvering within this competitive situation, former slaves and their allies sought resources and political voice, both within and outside the ranks of armed opposition to Spanish rule. Though no broad public debate was ever engaged on the possibility of conferring landed property - as reparations or otherwise - on former slaves, the colonial government did concede substantial civil rights and finally expanded the franchise to many black men in a last-ditch effort to fend off anti-colonial rebellion. Rebellion exploded nonetheless, and former slaves and their kin were conspicuous in the ranks of the cross-racial, cross-class independence struggle. ${ }^{2}$

Once Spain was defeated in 1898, former slaves and their descendants could invoke the break with the past, and often their own patriotic service in the Liberation Army, as a basis for claiming new rights and full citizenship. Such assertions, however, quickly ran up against bedrock commitments to private property and limited suffrage on the part of the U.S. Military Government that ruled Cuba from 1899 to 1902 , and revealed the reluctance of some elements of the

carried out an impressive cataloguing and reorganization of the Atkins Family Papers, following preliminary work by David Sartorius. Kathleen Lopez, with support from the University of Michigan Rackham Graduate School, transcribed key portions of the Soledad Plantation correspondence.

A first draft of this paper was presented at the Taller Bilateral Jardín Botánico de CienfuegosHarvard, held in November of 1999, and published in Spanish in Illes i Imperis (Barcelona) 5 (Fall 2001). Expanded versions were delivered at the conference, "L'héritage de l'esclavage et de l'émancipation en Europe et en Amérique," Saint-Claude, Guadeloupe, 9-11 March 2001; at the November 2001 meetings of the Southern Historical Association in New Orleans; and at the Yale Legal History Forum. We thank participants in each of those gatherings, and especially Joseph Reidy, for their comments.

1 On varying conceptions of property, see, among others, Carol M. Rose, "Possession as the Origin of Property" and "Property as Storytelling: Perspectives from Game Theory, Narrative Theory, Feminist Theory," both in Carol M. Rose, Property and Persuasion: Essays on the History, Theory, and Rhetoric of Ownership (Boulder, Colo.: Westview Press, 1994). On "a person with a price" as one vernacular definition of the slave relation, see Walter Johnson, Soul by Soul: Life Inside the Antebellum Slave Market (Cambridge, Mass.: Harvard University Press, 1999).

2 On the campaign for civil rights, see Oilda Hevia Lanier, El Directorio Central de las Sociedades Negras de Cuba, 1886-1894 (Havana: Editorial de Ciencias Sociales, 1996); and Raquel Mendieta Costa, Cultura: Lucha de clases y conflicto racial, 1878-1895 (Havana: Editorial Pueblo y Educación, 1989). On the war, see Orlando García Martínez, "La Brigada de Cienfuegos: Un Análisis Social de su Formación,” and Michael Zeuske, “'Los Negros Hicimos la Independencia': Aspectos de la Movilización Afrocubana en un Hinterland Cubano. Cienfuegos entre Colonia y República," in Fernando Martínez Heredia, Rebecca J. Scott, and Orlando García Martínez, eds., Espacios, silencios y los sentidos de la libertad: Cuba, 1878-1912 (Havana: Editorial Unión, 2001), pp. 163-92, 193-234. 
Cuban leadership to challenge those commitments. The result was a complex, multi-sided struggle to define the boundaries of freedom, the content of citizenship, and the pattern of access to resources. ${ }^{3}$

The theoretical outlines of this classic postemancipation and postcolonial problematic are relatively clear. ${ }^{4}$ It is the lived experiences, the on-the-ground dynamics, and the outcome of the struggle that have proven difficult to capture. The strategy for our current inquiry emerged from a conversation a few years ago on a small farm in Cienfuegos, Cuba, with the children of Cayetano Quesada. Cayetano Quesada was born in 1878 to slave parents on the Santa Rosalía plantation, and he enlisted at the age of seventeen in the multiracial Cuban rebel army fighting against Spain. He survived the war, and settled on a piece of land in the hamlet of San Antón. Four of his children, including Ramona Quesada, still live on or near that land. Toward the end of our first visit to the farm, one of us asked Ramona Quesada how her father had acquired the land. She replied, "por herencia"-by inheritance. A complex story has come down through family tradition about a dishonest neighbor who made off with crucial papers, leaving a strong sense that the land was their father's, but that this was not provable. Ramona Quesada believed that someone had stolen the documents; one of her brothers was unsure whether their father had ever held formal title. ${ }^{5}$

Upon reflection, we were curious about the concept of "inheritance" as a mechanism of property acquisition for a man born to two slave parents. There was no evidence that the owner of the Santa Rosalía plantation-an intransigent Spaniard named Manuel Blanco-had allowed former slaves to settle on lands owned by that estate, much less conveyed title to the land to them. The pension request filed by Cayetano Quesada in the 1930s listed his residence in San Antón as being on land belonging to the immense American-owned Soledad sugar plantation. The registrars at that date certified that his name appeared in no local property register. ${ }^{6}$ In what sense was the farm his, and what

\footnotetext{
3 On the complexity of the 1899-1902 period, see Louis A. Pérez, Jr., Cuba Between Empires, 1878-1902 (Pittsburgh: University of Pittsburgh Press, 1983); Rebecca J. Scott, "Race, Labor, and Citizenship in Cuba: A View from the Sugar District of Cienfuegos, 1886-1909," Hispanic American Historical Review 78 (Nov. 1998):687-728; and the 2001 University of Havana doctoral thesis of Marial Iglesias Utset, "Las metáforas del cambio: transformaciones simbólicas en el tránsito del 'entre imperios' en Cuba (1898-1902)."

4 The literature on these questions is now abundant. See Rebecca J. Scott, Thomas C. Holt, Frederick Cooper, and Aims McGuinness, eds., Societies after Slavery: A Select Annotated Bibliography of Printed Sources on Cuba, Brazil, British Colonial Africa, South Africa, and the British West Indies (Pittsburgh: University of Pittsburgh Press, 2002). For an explicitly comparative discussion that encompasses the U.S. South, see Frederick Cooper, Thomas C. Holt, and Rebecca Scott, $B e$ yond Slavery: Explorations of Race, Labor, and Citizenship in Postemancipation Societies (Chapel Hill: University of North Carolina Press, 2000).

5 Interview by Rebecca Scott with Ramona Quesada de Castillo and her family, June 1998, San Antón.

6 See the 1936 pension request of Cayetano Quesada in leg. 477, Juzgado de Primera Instancia, Cienfuegos, Archivo Provincial de Cienfuegos (hereafter APC). On the formation of the property
} 
did the Quesada family have in mind when they used the phrase "por herencia"?

Keeping in view both the general question and the specific remark made by Ramona Quesada, we began to explore several aspects of the question of access to productive resources after slave emancipation. We started on the ground-with pigs and horses, moveable property par excellence. We then looked at houses and house lots, both in town and in the country. Finally, we reached the question of cultivable land itself. Our aim was to explore the links between property and citizenship in two different directions. First, we asked how former slaves, as new citizens, might have sought to acquire property. ${ }^{7}$ Second, we asked how their status as propertyless or property holders might have shaped the content of their citizenship, particularly their exercise of the vote. We focused our lens on a rural county in central Cuba with a complex social structure and a rich regional archive: Cayetano Quesada's home territory of Cienfuegos.

The district of Cienfuegos, on the south coast, has long been one of the island's premier sugar-producing regions. ${ }^{8}$ Several rivers empty into the bay and the sea nearby, their broad valleys providing fertile soil and easy transport (see Map 1). To the east rise the Escambray Mountains, and to the west sprawls the vast Zapata Swamp and the Bahía de los Cochinos (Bay of Pigs). Rural Cienfuegos was home to thousands of slaves and, later, to a large, multiracial, and often militant rural proletariat. But on the edges and in the interstices of this plantation world, former slaves and other rural people also planted subsistence and market crops, grazed animals, and built lives in intimate relationship with, but not defined by, labor in the cane fields.

On the Soledad and Santa Rosalía plantations, located side by side on the Caunao River a few miles from the coast, a succession of late nineteenth-century administrators maintained a regular correspondence with the respective owners, Edwin F. Atkins in Boston and Manuel Blanco in the city of Cienfuegos. This documentation inadvertently reveals claims to property made by former slaves, those who had so recently been held to be property themselves. A

registers in 1884, see Manuel Martínez Escobar, Las inscripciones: Con toda la jurisprudencia civil e hipotecaria relacionada con las mismas, 2 vols. (Havana: Jesus Montero, n.d.).

7 For earlier explorations of postemancipation land tenure, see Rebecca J. Scott, Slave Emancipation in Cuba: The Transition to Free Labor, 1860-1899 (Princeton: Princeton University Press, 1985), ch. 11; Fe Iglesias, “Algunos aspectos de la distribución de la tierra en 1899," Santiago 40 (Dec. 1980):119-78; and Louis A. Pérez, Jr., Lords of the Mountain: Social Banditry and Peasant Protest in Cuba, 1878-1918 (Pittsburgh: University of Pittsburgh Press, 1989), chs. 3, 4. A powerful cautionary essay is Brian Pollitt, "Some Problems in Enumerating the 'Peasantry' in Cuba," The Journal of Peasant Studies 4 (Jan. 1977):162-80.

8 See Orlando García Martínez, "Estudio de la economía cienfueguera desde la fundación de la colonia Fernandina de Jagua hasta mediados del siglo XIX," Islas 55-56 (Sept. 1976-Apr. 1977). See also the discussion by Fe Iglesias on pp. 103-21 of Laird Bergad, Fe Iglesias García, and María del Carmen Barcia, The Cuban Slave Market, 1790-1880 (New York: Cambridge Univ. Press, 1995), and her essay in Martínez et al., Espacios, silencios, pp. 85-107. 
PROPERTY IN WRITING, PROPERTY ON THE GROUND 673

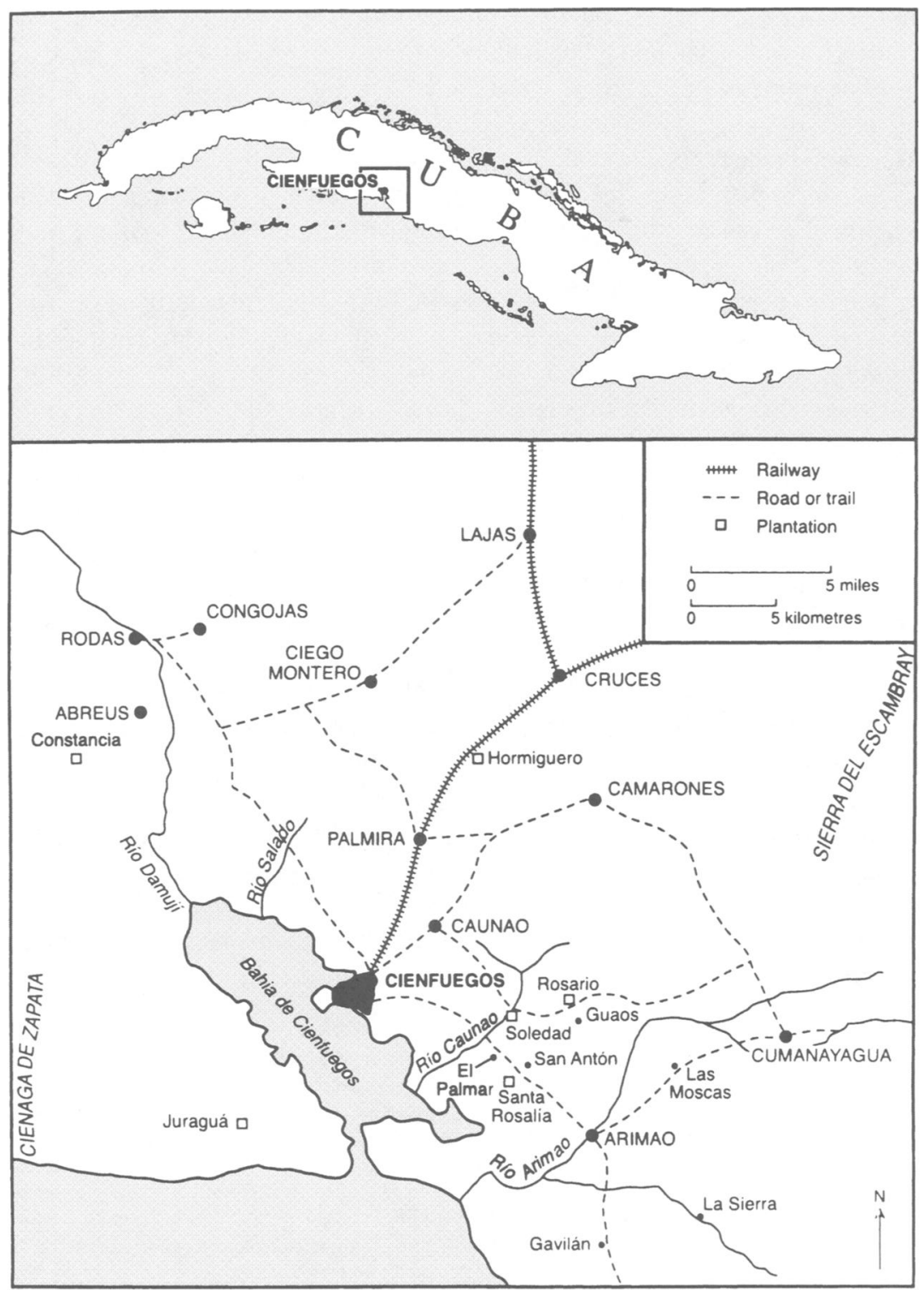

MAP 1. The Cienfuegos region, showing selected plantations. Map courtesy of the Past and Present Society. 
short distance to the north lie the sugar towns of Santa Isabel de las Lajas and Cruces, for which detailed municipal records have survived that reflect patterns of urban property in the last years of the colony and the first years of the Republic. By looking at Soledad and Santa Rosalía on the one hand, and the Lajas region on the other, we can glimpse something of the dynamics of access to resources on plantations themselves and in the sugar towns alongside them. What we find are multiple strategies for pursuing productive resources, some involving customary rights, some resting on political claims, and still others requiring direct engagement with law and the formal system of property. A single regional case study of this kind obviously cannot answer the broad question of how property relations are redefined in the aftermath of slavery. ${ }^{9}$ A narrative focused on property claims in a mixed-farming region, moreover, should not be taken as representative of the circumstances facing former slaves in the plantation zone of Matanzas to the west, or in areas of accelerating foreign investment like Camaguiey to the east. ${ }^{10}$ But it can suggest the complexity of the evidence that will need to be accounted for in any general explanation-and may hint at the importance to rural dwellers today of the negotiations undertaken by the generation that emerged from slavery.

\section{MOVEABLE PROPERTY: PIGS AND HORSES}

An exploration of former slaves and property might logically begin with that most classic vehicle of subsistence and investment: the pig. Throughout the nineteenth century, observers of Cuban plantations were agreed about the importance of pigs for the daily life of many slaves. Through a web of unwritten arrangements and understandings, slaves obtained piglets, then fed them corn held back from their own rations, or grains and root crops from their provision grounds. Once full-grown, the hog could be sold to the planter or to an itinerant merchant. Pigs functioned as a kind of savings bank, eating up available

\footnotetext{
9 Important studies have been done on postemancipation peasantries elsewhere in the Caribbean, often drawing on the pioneering work of the anthropologist Sidney Mintz. See his "A Note on the Definition of Peasantries," Journal of Peasant Studies 1 (Oct. 1973):91-106; the contributions by Mintz, Richard Frucht, and Woodville Marshall in Michael Craton, ed., Roots and Branches: Current Directions in Slave Studies (Toronto: Pergamon Press, 1979); the works of Jean Besson, including "Land Tenure in the Free Villages of Trelawny, Jamaica: A Case Study in the Caribbean Peasant Response to Emancipation," Slavery and Abolition 5 (May 1984):3-23; Thomas C. Holt, The Problem of Freedom: Race, Labor, and Politics in Jamaica and Britain, 1832-1938 (Baltimore: The Johns Hopkins University Press, 1992); and Veront M. Satchell, From Plots to Plantations: Land Transactions in Jamaica, 1866-1900 (Mona, Jamaica: Institute of Social and Economic Research, University of the West Indies, 1990).

${ }^{10}$ On the complexity of generalizing in a situation of marked regional differentiation, and where the categories of "agricultural worker" and "peasant" often overlap, see Pollitt, "Some Problems." On the contrast between established property regimes in central Cuba and the more rapidly transformed patterns in the east, see Alan Dye, Cuban Sugar in the Age of Mass Production: Technology and the Economics of the Sugar "Central," 1899-1929 (Stanford: Stanford University Press, 1998). See also César J. Ayala, American Sugar Kingdom: The Plantation Economy of the Spanish Caribbean, 1898-1934 (Chapel Hill: University of North Carolina Press, 1999).
} 
corn and scraps, and accruing cash value. ${ }^{11}$ They were also a source of cultural capital -if selling a pig gave access to cash, killing a pig made it possible to have a proper fiesta.

During slavery itself, there was an implicit transitivity to the property relations involved: the master owned the slave, who owned the pig, which ate products from the master's land, cultivated by the slave. The different meanings of "ownership" combined law and custom, but they were not in fundamental contradiction with each other. There was tugging and hauling over who had how much right to what within a nested set of ownership relations, but whatever the formal constraints on property owning by slaves, virtually everyone recognized that enslaved laborers could raise pigs and pocket the proceeds. ${ }^{12}$

As gradual slave emancipation began in the 1870 s, and the purchase price of a slave fell relative to the selling price of a pig, a new tension appeared. The raising of pigs came to be both substance and symbol of access to personal freedom: by selling several pigs, a family could sometimes accumulate enough money to buy the freedom of one or more of its members. Ownership in the legal sense - of the slave by the master - could be brought to an end through the activation of ownership in the customary sense-of the pigs by the slave. When J. S. Murray arrived on the Soledad plantation in 1884 as an administrator for the new owners, E. Atkins and Company, he immediately noticed the extent of this phenomenon. He reported to the plantation owners on the monies he was taking in from patrocinados ("apprentices," as bound laborers were designated in this last phase of emancipation) who wished to buy their freedom, and he noted that many of the funds were coming from the sale of hogs the patrocinados had raised. He even admitted privately that some of the patrocinados purchasing their freedom were over the age of sixty, and thus technically already free. ${ }^{13}$

In one sense, these self-purchases were a windfall for the plantation. The 1870 Moret Law had legally declared slaves free when they reached age sixty, but age was difficult to prove. Those patrocinados on Soledad whose ages had been fal-

11 The classic work on pigs and implicit rights in an urban context is Hendrik Hartog, "Pigs and Positivism," Wisconsin Law Review (1985):899-935. On pigs in Cuba, see R. Scott, Slave Emancipation, pp. 144, 150, 159, 160.

12 Within Spanish colonial law, most formal debate concerning the control of property by slaves invoked the Roman law concept of peculium, translated as peculio. Opinions ranged from an insistence that all property controlled by the slave belonged entirely to the master, to acknowledgement of the right of the slave to acquire, and pass on to heirs, a "modest quantity" of property. See the various provisions and proposals in Javier Malagón Barceló, Código Negro Carolino (1784) (Santo Domingo: Ediciones de Taller, 1974), especially pp. 123-24, 199-201. See also Manuel Lucena Salmoral, Los códigos negros de la América español (Alcalá de Henares: Ediciones UNESCO, 1996).

13 Murray recorded payments totaling $\$ 548$ from six patrocinados in June of 1884. Three of them (Victor Gangá, whose age was listed as fifty-two; Benicia Criolla, listed as forty-nine; and Eduvijes, fifty-one), were "in reality over sixty years of age, therefore free according to law." The previous owner had apparently falsified his slaves' ages in order to prevent their coming under the terms of the 1870 Moret Law. See the letter of J. S. Murray to E. F. Atkins, 19 June 1884, Box 1, Series IV, Soledad Sugar Co. Records, 1884-1916, Atkins Family Papers [Ms. N-297] (hereafter, Atkins FP), Massachusetts Historical Society (MHS). 
sified by the previous owner were now paying cash to assure the freedom that should have been theirs under law. But all self-purchases moved workers into the category of libertos, further out from under Murray's direct authority. Moreover, the presence of animals not owned by the plantation undermined his control over people and space. In May of 1885 he cracked down: "I have given order to negros to sell all their hogs, prohibiting in the future the raising of hogs." He offered to increase the workers' monthly stipend by 50 cents as a recompense, but he then went on to order them to sell their horses as well. Murray had long been irritated by the fact that "almost every negro on the estate owns a horse and they are a source of constant trouble in some way," and his letters reflect a continuing campaign to force the workers to get rid of them. ${ }^{14}$

Murray's efforts were counterproductive. There was an immediate work stoppage among the freedmen, and a few days later "all the libertos rebelled." When they refused his terms he ordered them off the estate, grumbling, "we are better without them as they are now only working when they feel like it, and keeping up a constant loafing during the day in the ranchos." 15 Eventually, however, Murray took them back. He needed their labor; they needed their huts and provision plots.

It is not clear how former slaves on Soledad had acquired horses, but the records of the neighboring Santa Rosalía plantation provide an occasional hint. Already during the last months of the apprenticeship system one former slave on Santa Rosalía used his accumulated stipends to buy a cloak and a saddle through the estate store. He also took out a large loan-perhaps to buy a horse to go with the saddle - and then worked to pay it back. For this man, Felipe Criollo, acquiring a horse may have been one of the first major purchases that could both symbolize and embody freedom. ${ }^{16}$ Horses brought mobility, and a degree of masculine authority and public standing as well. For all of Murray's bluster, it was clear that no simple fiat would easily persuade men, once in possession of a horse, to dismount and approach the world on foot.

Murray's references to hogs, horses, and "loafing" in the ranchos (huts with small plots of land) suggest that an internal economy, the lineal descendant of the old system of slave provision plots, was alive and well at Soledad. ${ }^{17}$ Mur-

14 J. S. Murray to E. F. Atkins, 1 July 1884, 21 Oct. 1884, Box 1, Series IV, Atkins FP, MHS.

15 See J. S. Murray to E. F. Atkins, 26 May 1885, 2 June 1885, Box 1, Series IV, Atkins FP, MHS. The patronato as a system of control was breaking down at the same time. Murray reported on 26 May 1885: "Thirty one (31) patrocinados obtained their liberty through the government and of our best men and women have bought theirs 40 in all, and no doubt more will buy their liberty as soon as the hogs are sold."

16 See f. 55 and 57, "Libro No. 1 de los negros, Santa Rosalía," APC. For a discussion of this same evidence in a different context, see Rebecca J. Scott, "Reclaiming Gregoria's Mule: The Meanings of Freedom in the Arimao and Caunao Valleys, Cienfuegos, Cuba, 1880-1899," Past and Present 170 (Feb. 2001):181-216.

17 The literature on such systems in other slave societies is abundant. See in particular Ira Berlin and Philip D. Morgan, eds., Cultivation and Culture: Labor and the Shaping of Slave Life in the Americas (Charlottesville: University Press of Virginia, 1993). 
ray tried to trim it down, but in doing so he encountered a point of immediate resistance by the estate's former slaves. His harsh methods-he placed some libertos in the stocks-reflected the increasing difficulty of maintaining strict control over the behavior of men and women who had access to food and animals through customary rights that did not pass through the wage nexus. Over time, under the new management at Soledad, rations would be more rigidly controlled and former slaves would find it more difficult to raise animals. But the difficulties that Murray encountered reflected the deep roots of that internal economy, and the proliferation of claims to animals to which it had given rise. These claims, moreover, were not easily countered, for the property itself could be moved (and hidden, if need be), and former slaves could back up their claims by threatening to withhold their labor.

\section{HOUSE LOTS}

Land and huts were even more important than pigs, and even more contested. When a former slave asserted the right to stay under his or her own roof, or to build a house on the land on which the plantation laborers lived, the claim did not fit well within the web of property relations mapped out in the notarial records or the property register. Spanish property law distinguished between relations of posesión (possession) and those of dominio (dominion). ${ }^{18}$ The law was sharp in holding that crops planted, and buildings constructed, even in good faith, on land legally owned by another became the property of the landowner-though it could call for reimbursement of expenditures. ${ }^{19}$

The Spanish Civil Code, introduced in 1889 and applied to Cuba in 1890, did hold that rights of dominio could be extinguished over time through prescripción (prescription), at which point a squatter who could prove lengthy possession would acquire a recognized claim. This doctrine rested on the old Roman concept of prescription, which in Spanish civil law made room for formal claims parallel to those that in Anglo-American common law would be based on the doctrine of adverse possession. ${ }^{20}$ But the process required thirty years

\footnotetext{
18 For a detailed and systematic survey of Spanish property law as it was transformed in the Antilles, see Michel J. Godreau and Juan A. Giusti, "Las Concesiones de la Corona y la Propiedad Territorial en Puerto Rico, Siglos XVI-XX," Revista Jurídica, Universidad de Puerto Rico 62 (1993), 351-579.

19 See Rafael Pérez Lobo, Codigo Civil y Constitución (Havana: Cultural, S.A., 1944), especially Libro Segundo, Títulos I and II, of the 1889 Spanish Civil Code. Article 361 holds that, " $E l$ dueño del terreno en que se edificare, sembrare, o plantare de buena fe, tendrá derecho a hacer suya la obra, siembra o plantación, previa la indemnización establecida en los artículos 453 y 454 , o a obligar al que fabricó o plantó a pagarle el precio del terreno, y al que sembró la renta correspondiente."

20 We are grateful to Bruce Frier and Carol Rose for their explanations of the subtleties of Roman and Continental law on this point. They emphasize the strong preference given to the title holder, and the centrality of the property register. For Cuba, see articles 1930 and 1959 of the Civil Code, in Pérez Lobo, Codigo Civil y Constitución. Art. 1930. "Por la prescripción se adquieren, de la manera y con las condiciones determinadas en la Ley, el dominio y demás derechos reales. También se extinguen del propio modo, por la prescripción, los derechos y las acciones de cualquier
} 
of posesion in the case of intentional occupancy of land owned by someone else. While some absentee (or absent-minded) owners might fail to prevent such a situation from developing, this doctrine was of little immediate use to former slaves, for their occupancy of dwellings during slavery apparently generated no rights enforceable at law. What claims they made would have to be asserted through various forms of customary understandings. ${ }^{21}$

Only occasionally does the written record provide an echo of the oral exchanges in which former slaves' assertion of a right to shelter was voiced. By happenstance, Soledad plantation hosted an exceptionally observant winter visitor in 1890. Charles Francis Adams II, grandson of former U.S. president John Quincy Adams, spent the month of February with his old friend from Boston, Edwin Atkins, staying in the casa de vivienda (the owners' residence) and going riding in the neighborhood each morning. Adams's wry letters home to his wife are marked by a characteristic turn-of-the-century racism and a patronizing, ironic tone. But in his effort to convey the flavor of daily life, Adams recorded scenes that would otherwise be lost, and captured exchanges that one can interpret in ways that he would not have. His description of an encounter between an unnamed former slave, returned from the city of Cienfuegos, and the Soledad owner and administrator, is vivid:

The only diversion was the return to the plantation of a hideous old African woman, who it seems is a privileged character. Mr. Murray, the manager of the place, intimated that he suspected she had been down to Cienfuegos, where she has a grand-daughter, impelled by the love of strong drink; but the old lady herself met us on our arrival, and, with many gestures and much volubility, informed Mr. Atkins that she had gone there for the benefit of sea-bathing, and she now desired him to direct Mr. Murray to provide her with a small piece of land and a house, for her greater convenience in living. She is a sociable old party and gives me the advantage of many speeches in negro-Spanish,squatting about all the while like a deformed monkey. ${ }^{22}$

What the visitor from Boston found risible, the unnamed "sociable old party" found perfectly logical: that after a lifetime of labor on Soledad she should spend her final days there, with access to land to enable her to provide for a part of her own subsistence. What better moment to make a claim than during a visit by a distinguished guest, when Atkins might feel obliged to accede ${ }^{23}$

clase que sean." Art. 1959. "Se prescriben también el dominio y demás derechos reales sobre los bienes inmuebles por su posesión no interrumpida durante treinta años, sin necesidad de título ni de buena fe, y sin distinción entre presentes y ausentes, salvo la excepción determinada en el art. 539."

21 On the general question of land, law, and custom, see Edward P. Thompson, Customs in Common (London: Merlin Press, 1991).

22 See the undated letter headed "The Plantation 'Solidad," Charles Francis Adams II to Mary Ogden Adams, 1891, in Box 35, the papers of Charles Francis Adams II (hereafter CFAII P), MHS.

${ }^{23}$ For a discussion of the Adams visit, see Rebecca J. Scott, "A Cuban Connection: Edwin F. Atkins, Charles Francis Adams II, and the Former Slaves of Soledad Plantation," presented at the Massachusetts Historical Society, May, 1999, and scheduled for publication in a guide to the Atkins Family Papers, forthcoming from the Massachusetts Historical Society. 
It was obviously difficult to make any such claim stick. Moreover, not all former slaves wished to remain on or near the plantation on which they had been enslaved, or could find a way to do so. For some, settling in town seemed the only or the more attractive option. Oral tradition in the family of Tomás Pérez y Pérez holds that his mother, Bárbara Pérez, was expelled from the Santa Teresa plantation on which she had been a slave, and made her way "en caravan" with other former slaves to the nearby town of Arimao, where they sought permission from local landholders to build houses of palm thatch. They became, in effect, tenants-at-will, with all the vulnerability that implied (see Photograph 1). ${ }^{24}$

As in the United States, the central government in Cuba made no lasting commitment to the provision of land for former slaves. A resettlement program of sorts had been undertaken in the late 1870 s, directed at rebels who had surrendered to Spanish forces, and at other Cubans whose loyalty might be boughtor so the colonial state hoped-with small plots of land in closely supervised settlements. One such community was established in Congojas, north of Cienfuegos. The intended beneficiaries, however, were former rebels, only some of whom were also former slaves, and the impact of the government programs appears to have been modest. ${ }^{25}$

Mechanisms of patronage and private pursuit proved more accessible to former slaves. In the sugar town of Santa Isabel de las Lajas, settlement by former slaves very early took on a surprisingly formal and durable character. Lajas was in 1885 a prosperous municipal cabecera (principal town) of 8,000 residents, with two newspapers and a lively associational life. The town bordered on the immense Caracas plantation, and popular memory in Lajas attributes to the powerful planter family of Emilio Terry the donation of a tract of land along the Calle del Ferrocarril (Railroad Street) to a group of his former slaves. These lands were situated at the margin of the town itself, and they came to be seen as a "black" settlement (see Map 2). Historians, linguists, and ethnographers working in the area in the 1970s were told that the Terry family had in 1885-1886 distributed parcels of land on which former slaves built wooden board houses with palm-thatch roofs. ${ }^{26}$

The families in this neighborhood often carried the surnames Terry or Moré,

24 Interview by Rebecca Scott with Tomás Pérez y Pérez, March, 1999.

25 See Ada Ferrer, Insurgent Cuba: Race, Nation, and Revolution, 1868-1898 (Chapel Hill: University of North Carolina Press, 1999), pp. 73, 100-4. Imilcy Balboa Navarro, "Colonización y poblamiento militar versus independencia. Cuba 1868-1895," Rábida (Huelva) 17 (1998):12138; Balboa Navarro, Los brazos necesarios. Inmigración, colonización y trabajo libre en Cuba, 1878-1898 (Valencia: Centro Francisco Tomás y Valiente UNED Alzira-Valencia, 2000), pp. 49-66. On Congojas, see "Congojas y San Agustín," in "Política, Poblados," Feb. 1877, leg. R-427, División 3a, Sección 2a, Fondo Ultramar, Archivo General Militar, Segovia, Spain.

26 Gema Valdés Acosta, "Descripción de remanentes de las lenguas bantues en Santa Isabel de las Lajas," Islas 48 (1974):67-85; Rosalía García Herrera, "Observaciones etnológicas de dos sectas religiosas afrocubanas en una comunidad lajera: la Guinea," Islas 43 (Sept.-Dec.1972): 145-81; and John Dumoulin, "El primer desarrollo del movimiento obrero y la formación del proletariado en el sector azucarcero. Cruces 1886-1902," Islas 48 (1974):3-66, especially p. 19. 
and included the grandparents of the future musician Benny Moré. The settlement came to be known as "la Guinea," and was referred to as a "land of Congos." Residents of la Guinea apparently referred to the back of that settlement using terminology that echoed the racist labeling of the time: La Cueva de los Monos-Monkey Cave. ${ }^{27}$ This "gift" of land by Terry seemed to scholars in the 1970s to represent a reformist, paternalistic maneuver designed to assure a labor force in the Caracas sugarmill, and thus to be part and parcel of the continued exploitation of black labor. ${ }^{28}$

If one goes to the archives, and then returns to carry out new interviews, a somewhat different picture emerges. ${ }^{29}$ Many of the residents of la Guinea held legal title to urban plots measuring some 1000 varas (a little less than 700 square meters). Tracing these titles back through the notarial records, one finds documentation not of gifts but of the purchase of land by former slaves. The sellers were people like Bárbara González Mesa, daughter of one of the major cane farmers of Lajas, former owner of the Santa Sabina (later Caracas) plantation. These landowners conveyed the title through sale, at a price of 50 pesos for an empty house lot. The first sales date from 1877, and many of the purchasers were women who had recently been slaves. ${ }^{30}$

Later, in June of 1883, Don Julián Romero sold similar empty land to "the morenas libres (free blacks) Mónica and Victoria de la Torre . . from Africa." They were identified as being without profession, single, aged thirty and fortyfour years, residents one of Lajas and the other of Sagua la Grande. The seller, Romero, born in Santa Clara, worked in the country and lived in Lajas. The land itself came from property that had previously belonged to Bárbara Gonzalez, and it bordered the lot belonging to a woman identified as "the morena Antonia Terry." 31 One possible interpretation is that Mónica and Victoria de la Torre were two sisters who had been separated by slavery, and who now were able to live together. Another is that they were former slaves of the same owner who were joining forces to set up a new household.

27 See García Herrera, "Observaciones,” pp. 145-46, and the discussion in Michael Zeuske, "Guinea in Kuba oder zurück nach Afrika," in Matices. Zeitschrift zu Lateinamerika-SpanienPortugal (Köln) 2 (1994):6-9. On an earlier use of the term "Guinea," see Dale Tomich, "Une Petite Guinée: Provision Ground and Plantation in Martinique, 1830-1848," in Berlin and Morgan, Cultivation, pp. 221-42.

28 See García Herrera, "Observaciones."

29 Extensive documentation on Lajas is held in the notarial records and the Fondo Ayuntamiento de Lajas of the APC.

30 Most of the sales are found in Protocolos de José Rafael Villafuerte y Castellanos in the APC. See, for example, "Venta de terreno yermo," Escritura no. 97, 14 June 1883, f. 412r.-415v., and "Venta de solares yermos por Dn Julián Romero Rodríguez a los morenos libres León y Natalia Fortún," Escritura no. 98, 14 June 1883, f. 418r.-421r. An earlier sale, to the morena libre Filomena Viera, born in Africa, is "Venta de solares," Escritura no. 149, 13 July 1878, appears on f. 387r.-388v., Protocolos D. José Rafael Villafuerte y Castellanos.

31 See "Venta de terreno yermo," Escritura no. 97, 14 June 1883, f. 412r.-415v., Protocolos D. José Rafael Villafuerte y Castellanos, APC. 
León and Natalia Fortún, also morenos libres, bought from Julián Romero a house lot on which their descendants still live. The buyers were listed as "the free blacks León and Natalia Fortún, without second surnames, who come from Africa, single, ... fieldworkers," and this land too had originally belonged to Bárbara González. The price was 50 pesos. ${ }^{32}$ These were formal and documented sales, conveying dominio rather than the fragile hold of a squatter or the informal arrangement with which Bárbara Pérez had to manage in Arimao. Joaquín Palacios, a free black man born in Africa, for example, bought from Julián Romero two unnumbered house lots, and the notarized transaction specified that he received "the property and dominion with all its usages, and real and personal rights." 33

The development of landholding in the neighborhood called la Guinea thus apparently owed relatively little to paternalism by the local magnates, the Terry family. ${ }^{34}$ When new, formal property registers were created under Spanish law in the $1880 \mathrm{~s}$, the administrator of the Terry estates scrambled to find documentation that would enable them to register the fifty-eight urban lots (solares) that the family believed it owned in Lajas. ${ }^{35}$ Perhaps at this moment one or another donation of land was made to a former slave, but if so, it apparently left no trace in the record. The family does appear to have given funds to a community building, the Casino Congo San Antonio de Lajas, the cultural heart of the emerging neighborhood, and this may be the source of the memory of paternalistic grants of land. ${ }^{36}$ To judge by the documents we have located so far, however, sale by a local creole cane farmer was more important than gift by the Terrys, and 50 hard-earned pesos changed hands each time.

The many transactions of this kind suggest that the small-scale urban land

32 Interview by Orlando García, Félix Tellería, and Michael Zeuske, with Cándido Terry y Terry and Zenaida Armenteros Bejerano, 15 Mar. 2000. Terry and Armenteros generously showed us their property title, which is a copy of the original "Venta de solares yermos," Escritura no. 98, 14 June 1883, f. 418r.-421r., Protocolos D. José Rafael Villafuerte y Castellanos, APC.

33 The language is: "en venta real por juro de heredad y perpetuo traspaso al moreno . . y y sus sucedores [sic] . . . tramitiendo aquel la propiedad y dominio con todos los usos, derechos reales y personales," "Venta de solares yermos por D. Julián Romero Rodrígues al moreno libre Joaquín Palacios," Escritura no. 176, 8 Nov. 1883, f. 745r.-748r., Protocolos D. José Rafael Villafuerte y Castellanos, APC.

34 It is conceivable that there was a degree of fiction in these documents. As Jacques PoloniSimard points out in his discussion of notarized land transfers in colonial Ecuador, the creation of a written record may not accurately reflect the actual transfer of money. See Jacques Poloni-Simard, La Mosaïque Indienne: Mobilité, stratification sociale et métissage dans le corregimiento de Cuenca (Équateur) du XVI $I^{e}$ au XVIII siècle (Paris: Éditions de l'École des Hautes Études en Sciences Sociales, 2000), pp. 117-18. For the moment, however, we are assuming that these sales were actual sales, and that non-monetary grants of use rights, based on clientelist relations, were distinct from these notarized transactions, which generated a carefully-guarded paper trail.

35 Francisco Sánchez Marín (Cienfuegos) to Emilio Terry y Dorticós, 28 Oct. 1887, in “Correspondencia dirigida al Sr. Emilio Terry de los años 1887 y 1888," Signatura 72, Caja 63, Fondo Academia de la Historia, Archivo Nacional de Cuba (hereafter ANC).

36 On the Terry family, see also the recollections of Esteban Montejo in Miguel Barnet, Cimarrón (Havana: Instituto del Libro, 1967), p. 105. 
market in Lajas was an active one. Parallel with the process of slave emancipation in the countryside, a new racial geography thus developed in the towns that had attracted migrants, such that some years later observers would describe the neighborhood of la Guinea as composed of "Negro shacks." It also seems to have been at around this time that notaries began placing the new term "s.o.a." - sin otro apellido (without a second surname)-after the names of many people of color who engaged in notarized transactions. This usage singled out newcomers to the place and to the legal system, and marked them as illegitimate, lacking the crucial second surname that would signal married parents, or subsequent legal recognition by a father as well as a mother. Not for the first time, the holders of legal authority responded to initiatives on the part of Afro-Cubans by labeling them as deficient and out of place. ${ }^{37}$ Property was gained, but stigma was attached at the moment this victory was achieved. ${ }^{38}$

\section{CULTIVABLE LAND}

For some of those who migrated to town, and for many of those who did not, the primary goal remained the acquisition of rural property on which to plant subsistence and market crops. Like generations of free and freed people before them, they sought to establish sitios or estancias (each a traditional term denoting small farms) that could provide a base from which to engage the expanding world of sugar cane without submitting wholly to it. Often building on the demand for foodstuffs in urban markets, small farmers tried to create opportunities for autonomy in the face of changes that might otherwise engulf them. ${ }^{39}$

Former slaves could try to stake a claim to unoccupied cultivable lands, or put together funds to make a purchase. Both men and women scouted out the edges and niches in and around the large plantations, as well as the foothills of the nearby mountains. Already in the 1860 s and 1870 s, the correspondence of plantation owners and administrators had reflected a concern with the edges of their holdings. Masters and managers were worried that slaves would step out across those boundaries, and that bandits or cattle thieves would make their way inside the notionally closed world of the plantation. During the Ten Years' War

37 The "problem of the s.o.a." has been a continuing concern of Michael Zeuske in his work on this region. See his "Los negros hicimos la independencia," in Martínez et al., Espacios, and the essay "Hidden Markers, Open Secrets: On Naming, Race Marking and Race Making in Cuba," forthcoming in New West Indian Guide (Leiden, 2002).

38 A similar three-letter abbreviation, f.w.c. or f.m.c., free woman of color or free man of color, was mandated in antebellum Louisiana. See Judith Kelleher Schafer, Slavery, the Civil Law, and the Supreme Court of Louisiana (Baton Rouge: Louisiana State University Press, 1994), p. 271n. The distinctive feature of the Cuban s.o.a., however, is that it made no explicit reference to color.

39 Well before the beginning of gradual abolition, the census of 1862 counted nearly 40,000 free people of color living on small farms, though it did not indicate the proportions of owners, renters, squatters, or laborers among them. See the excellent overview by Carlos Venegas Fornias, "Estancias y Sitios de Labor: Su Presencia en las Publicaciones Cubanas del Siglo XIX," Colonial Latin American Historical Review 10 (Winter 2001):27-59. For an analysis that emphasizes the destructive impact of the expanding plantation economy on this sector, see Pérez, Lords of the Mountain. 
(1868-1878), runaway slaves at times joined forces with rebels, held out in the nearby hills, and doubled the threat to good order. ${ }^{40}$

Occasionally the move to the edges was encouraged by planters themselves. On 1 July 1879, the manager of the Santa Rosalía estate wrote with concern that Dn. Rafael Sarría, then the owner of the neighboring Soledad plantation, was permitting freed slaves to install themselves on open land along Santa Rosalía's property line, where they were establishing sitios, small farms. "Esto puede dar muy mal resultado en su día . . ." (This may in time lead to very bad results). ${ }^{41}$ One planter's concession was another planter's threat. It cost Sarría very little to give a former slave the use of a small plot of ground beyond the margin of the land worth planting in cane. The former slave could grow frutos menores ("minor crops" such as plantains, sweet potato, and yucca) without affecting the original owner's title to the land. This paternalistic gesture would pose no legal obstacle to eviction if the owner subsequently sought to replace such tenants-at-will (precaristas) with sugar cane or paying renters. ${ }^{42}$ Moreover, the settlement of former slaves at the edges could help to mark the outermost point of a large and ill-defined estate, and perhaps encourage encroachment on the land of a neighbor - as the administrator of Santa Rosalía seems to have feared.

What began as a convenience and a concession for the landowner could, however, become something quite different for the former slave. A sitio (small farm) was to the person who planted it not an ephemeral annual or seasonal planting to be harvested, consumed, and abandoned. The occupant generally built a house, planted tree crops that would take years to mature, and laid out living fences that marked corridors and boundaries with a sturdy and often spiny finality. A claim to the undisturbed use of the property was a physical and social affair as well as a matter of law. Indeed, as the economist Albert Hirschman has noted, there are occasions when the sturdiness of the buildings in a new settlement may be in inverse proportion to the security of the legal title. The squatter with a fragile tenancy may plant himself or herself all the more firmly in hopes of deterring demolition and eviction. ${ }^{43}$

Some planters' concessions of land were made without even the pretense of paternalism. In June of 1885, J. S. Murray, the administrator at Soledad, granted to "old and useless negros" what he characterized as "several lots" of "waste land on a hill," some distance from the mill yard that was the heart of the plantation (the batey). He planned to fence off the area so that the residents could

40 See the correspondence between the administrator and the owner of Santa Rosalía in Colección Manuscrita Julio Lobo, Colección Cubana, Biblioteca Nacional José Martí (hereafter CM Lobo, CC, BNJM).

41 See Francisco Pérez to Dn. Manuel Blanco, 1 July 1879, in No. 10, CM Lobo, CC, BNJM.

42 For a treatise on eviction, see Manuel Martínez Escobar, El desahucio y su jurisprudencia (Havana: Cultural, 1942), especially pp. 177-90.

43 See Albert O. Hirschman, Getting Ahead Collectively: Grassroots Experiences in Latin America (New York: Pergamon Press, 1984), pp. 1-6. See also Robert Ellickson, "Property in Land," Yale Law Journal 102 (Apr. 1993):1315-1400; and Rose, Property and Persuasion. 
not return to the batey. ${ }^{44}$ From the vantage point of Soledad's owners, the settlements that emerged from this process were derisory: "waste land" occupied by "the refuse of the place." Charles Francis Adams II recalled a ride out to "what they call 'China-town,' or the place set apart for the freed slaves, who yet remain about the plantation. It is a piece of refuse land, largely ornamented with field stone, and the children of Africa live thereon in habitations of palmbark and thatch." But for their residents, such settlements were the nuclei of social life, however stony the soil on which they had to build. ${ }^{45}$

Two additional points of semi-independent settlement along the edges of Soledad plantation were San Antón, on the southeastern corner of the property, and El Palmar, on its southern boundary (see Map 3). An 1880-1881 enumeration of non-sugar properties in the district provides a fleeting glimpse of the neighborhood, listing several sitios in the partido of Arimao that seem to correspond to settlements on the edge of Soledad. D. Joaquín Hernández owned a sitio called Palmar, and D. Antonio Ravella owned one called Caunital that apparently encompassed part of San Antón. The first paid only a small tax bill, suggesting that El Palmar was quite small; Ravella's holding was somewhat larger. Both owners were given the title Don, signifying social recognition as white, and as of this early date there is no hint of legally acknowledged landowning by people of color in this neighborhood. ${ }^{46}$

By the 1890s, some former slaves from Santa Rosalía seem to have settled down the hill from the plantation, toward Soledad, in the hamlet called San Antón. Among them may have been Alejandro Criollo, who seems to have found a foothold on the land and planted subsistence crops, while continuing to work seasonally on the Santa Rosalía plantation. Cayetano Quesada was one of his children, born around 1878, and free under the provisions of the Moret Law. Cayetano's sons believe that it was probably their grandfather Alejandro who planted the avocado tree that towers over their current house. ${ }^{47}$

We do not know quite how former slaves made these initial claims to land in San Antón-whether by settling on entirely open and uncultivated land

44 See J. S. Murray to E. F. Atkins, 16 June 1885, Box 1, Series IV, Atkins FP, MHS. This may have been a piece of land known as Paraíso, located toward the neighboring plantation of Rosario. At least one man with the surname Sarría lives there now, at the edge of the cane fields, and prides himself on his plantings of yuca (manioc) and calabaza (squash). (Interviews by Rebecca Scott with Lidia Girón and Lenny Sarría, 1999.)

45 Charles Francis Adams II to Mary Ogden Adams, undated (Jan. 1890), Box 35, CFAII P, MHS. The name "China-town" may come from Paraíso's location beyond the barracks and cemetery of Chinese laborers on the plantation.

46 See the properties numbered 288, 289, 290 in "Provincia de Sta Clara, Ayuntamiento de Cienfuegos, Fincas Rústicas no destinadas al cultivo del azúcar ni del tabaco, Copia del padron vigente para la distribución del impuesto municipal en el año de 1880-81," Exp. By, leg. 3097, Miscelánea de Expedientes, ANC.

47 Alejandro Criollo appears on the payroll of Santa Rosalía in the months of April and October, 1889. See Vol. 1, No. 159, CM Lobo, CC, BNJM. Marcelino Iznaga Suárez Román, now in his nineties, recalls that Cayetano Quesada's father was still called Alejandro Criollo by his friends, even after the end of slavery. Interview with the authors, 26 Feb. 2002. 


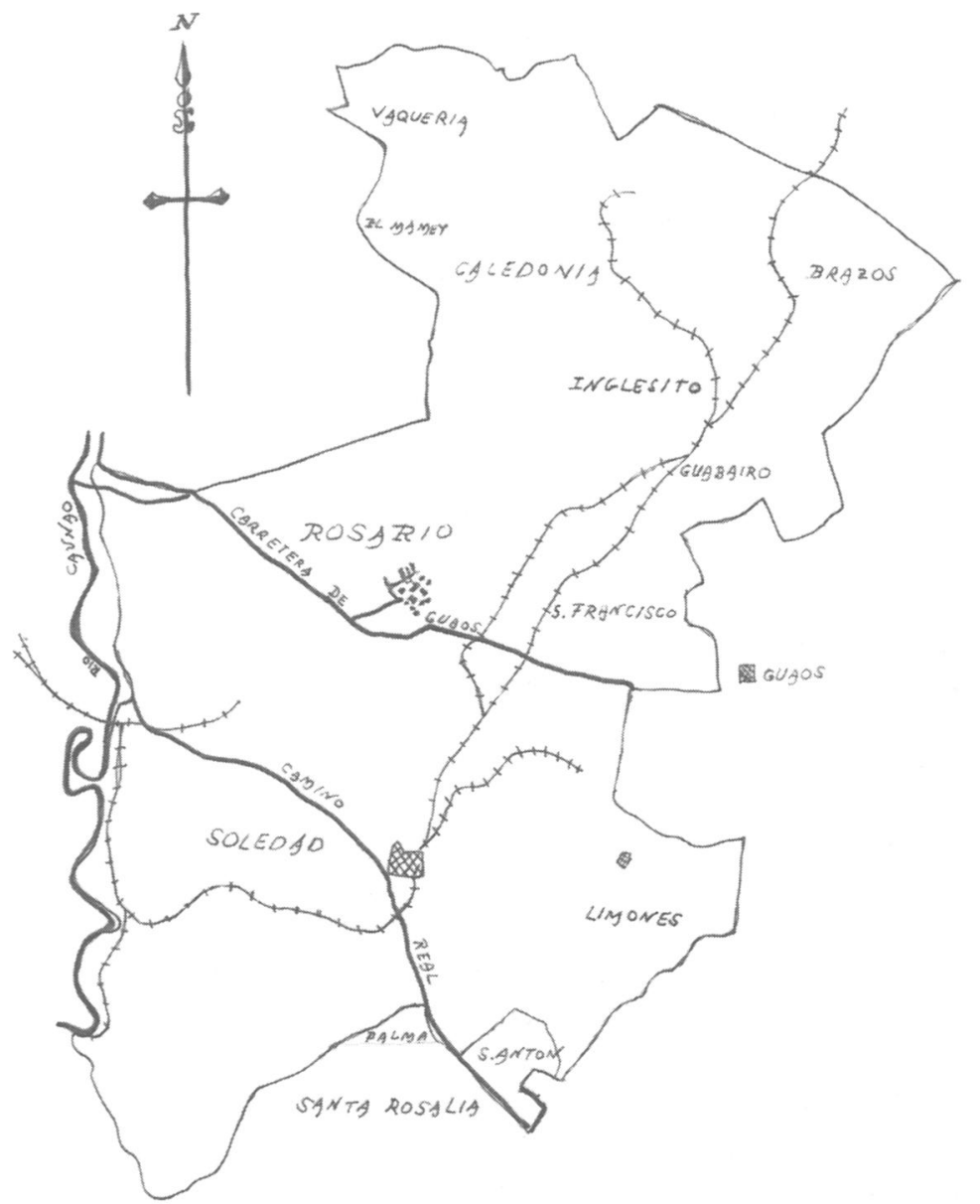

MAP 3. A sketch of the holdings of E. Atkins and Company, owners of the Soledad Plantation, in 1906. The hamlet of San Antón is at the lower right, and El Palmar (labeled Palma) is at the bottom center. Originally from a notarial recrd, the document is now in the map collection of the Archivo Provincial de Cienfuegos.

that still notionally belonged to the Spanish crown (realengo or terrenos baldios), or whether through relations of kin or clientage with existing settlers. San Antón as a place name has deep roots, and was the denomination of an early royal grant of grazing rights centered close to this spot, in the epoch when cattle-raising defined the region. The circular grants of land for grazing, called hatos or corrales, had been an incentive for Spanish settlement, but were also a machine for creating ambiguities and interstices, and the defining of boundaries was a perpetual conundrum within the Cuban proper- 
ty system. Over the years the heirs of the grantees and other owners came to hold pesos de posesion (fractional portions) of the undivided and unsurveyed rural properties, known as haciendas comuneras. In many instances titles had become vague, and in notarial records land was at times simply "said to be owned" by so-and-so. It is not difficult to see how it might be possible to settle on such land without any individual owner recognizing the intrusion. 48

In the initial years after emancipation there may also have been a symbiotic relationship between new squatters and some titular owners, including absentees who might find that having someone cultivate the land helped them to maintain their boundaries with their large planter neighbors. D. Antonio Ravella and his wife Da. María Carr, who held title to more than 170 acres around San Antón, lived in the city of Cienfuegos, where the husband was a contractor. They may not have known of, or objected to, the presence of a few discreet squatters on their pastureland outside of town. ${ }^{49}$

Such informal settlement, however, could change the social character of the neighborhood. At the outbreak of the 1895-1898 war, San Antón apparently harbored rebels who had declared allegiance to the separatist cause. The administrator at Soledad noted in a letter in August of 1895 that a group of Spanish soldiers leaving the plantation for the town of Arimao was ambushed by rebels shortly after passing beyond the boundary of the plantation-presumably just as they reached San Antón. ${ }^{50}$ One of these rebels may well have been Ciriaco Quesada, a former slave from the Santa Rosalía plantation who had worked only seasonally on the estate since acquiring his freedom in 1886, and who enlisted in the insurgent army in August of 1895. The captain of Ciriaco Quesada's company was a former slave from Soledad plantation, a cartman named Claudio Sarría. Their neighbor from Santa Rosalía, Cayetano Quesada, now age seventeen, may also have been involved in the ambush. Shortly thereafter he too formally signed up in the rebellion. ${ }^{51}$

Going "to the monte" — heading for the hills — was a synonym for joining the

48 For example, when Edwin Atkins later bought a 46-hectare paño of land (a cultivable plot) in San Antón, the notary recorded that it bordered on lands "said to be owned by Doña María Ravella de Saiz." See "Venta de fincas rústicas, derechos y acciones," Escritura no. 391, 2 Apr. 1906, f. 3248r.-3317r. Protocolo Fernández Pellón, APC.

49 For their title, see "Venta de finca rústica y promesa de venta de otras," 22 Nov. 1901, f. 7190r.-7120r., Escritura 1035, Protocolo Fernández Pellón, APC. The hypothesis of a clientelistic relationship between the Ravellas and some former residents of Santa Rosalía, perhaps accompanied by a hostility between Ravella and the owner of Santa Rosalía, Manuel Blanco, is born out by the appearance of Antonio Ravella as curador of the young widow of the estate's first owner when she tried to contest Manuel Blanco's inheritance of the plantation. See the legal documents from 1877 in No. 23, CM Lobo, CC, BNJM.

50 See Edwin F. Atkins, Sixty Years in Cuba (1926; reprint edition, New York: Arno Press, 1980), pp. 163-64.

51 For a detailed discussion of the war in the neighborhood, see Scott, "Reclaiming Gregoria's Mule." 
anti-colonial insurrection, and carried an implication of mobility. But the irregular warfare of the Cuban rebels involved cultivating crops as well as battling Spaniards. As the Cuban rebels gained control of land in the monte they cleared plots and planted provisions. And being a soldier in the rebellion was also not necessarily in contradiction with continuing to be a farmer or even a day laborer: Rafael Iznaga, like Ciriaco and Cayetano Quesada an infantryman in the rebel Cienfuegos Brigade, appeared on the pay list of the Soledad estate in January of 1898, while the war was still raging. His term of service in the insurgent army formally lasted until the end of the conflict, but seems to have encompassed periodic informal returns to the plantation. ${ }^{52}$

As the war drew to a close in the late summer of 1898 , the country people who had been the soldiers of the rebellion were in some cases already back at work on the land; in other cases they were desperately seeking land to work. It seems to have been at this moment that a group of veterans-black, mulatto, and white-returned or moved to San Antón, and began to carve out access to a larger tract of land. Several of the current residents of the neighborhood are descended from veterans, including not only the family of Cayetano Quesada, but also that of Zacarías González Castillo, a white man who had entered the rebellion along with other local men in September of 1895, and risen to the rank of corporal. ${ }^{53}$ The resettlement of San Antón seems to have been based on informal actions, but it left oblique traces in the written notarial records.

In 1901, Maria Ravella, who lived in Havana, formally sold to Soledad plantation a piece of land around San Antón that she had inherited from her parents, both of whom had died in 1897. The full plot of land in question measured $5 \frac{1}{2}$ caballerías (about 75 hectares, approximately 170 acres), and was located along the southeastern boundary of Soledad. Ravella sold four of the $\mathrm{ca}$ ballerías, but could not sell the fifth, over which she had dominio but not effective possession. The bill of sale specified that "the rest of the property, which remains in the hands of the seller, consists of two lots of land which are improperly possessed by other people, against whom she promises to exercise her rights, until she obtains possession, at which time she will sell it to Soledad ... for 600 pesos in Gold per caballería ... " 54

Several veterans seem to have been among the "other people" who had spearheaded the occupation of these fifty or so acres. They probably included Cayetano Quesada, the young son of slaves; Zacarías González, the white man who was one of his closest friends; José González, another white veteran; and perhaps Ciriaco Quesada, a former slave from neighboring Santa Rosalía. When

52 See the Soledad pay list for January 1898, among the Soledad volumes incorporated into the Fondo ICEA, ANC.

53 He appears on p. 378 of Carlos Roloff y Mialofsky, Indice alfabético y defunciones del Ejército Libertador de Cuba (Havana, 1901).

54 "Venta de finca rústica y promesa de venta de otras," Escritura no. 1035, 22 Nov. 1901, f.7109r.-7120r., Protocolo Fernández Pellón, APC. 
these men came back from the war in 1898, Cayetano's father may already have been living in a hut on the edge of the cattle lands. Some of the fields had been burned over during the fighting and were vacant. The senior Ravellas, who held title to a large tract, were dead. Edwin Atkins's attentions seem not yet to have been focused on the land adjacent to this corner of his plantation. There was space within which an assertive group of veterans could maneuver. ${ }^{55}$

Together or singly, but probably in concert, the veterans and their kin could clear and plant, building out from a prewar foothold to construct a new community in which boundaries were defined on the ground and in social recognition-but not in the property register. Within three years, their posesión would be quite visible - and a practical obstacle to the formal transfer of María Ravella's title to a third party. Legally, the Quesadas and González's could have been evicted from San Antón; socially, on the eve of the proclamation of a new Cuban Republic, perhaps not.

Smaller and more precarious than San Antón was El Palmar, a jib of land on the southern boundary of Soledad plantation, not far from the Caunao River. Too stony to be attractive for cane planting, the property was not in the original parcel acquired by Edwin Atkins in the 1880s. If one rode on horseback out what used to be the principal entrance to Soledad-now located behind the modern mill - and turned left, one would cross a small stream and then arrive at El Palmar. Never formally incorporated as a settlement, it was devastated by a hurricane decades ago. Up close, El Palmar looks like just another stretch of road with a few houses, though from a distance its splendid grove of royal palms stands out on the horizon. Today, one might be forgiven for passing right through without stopping. For the purposes of our study, it is precisely the unobtrusiveness of El Palmar that makes it worth noticing. A classic interstitial community, it grew up in the immediate aftermath of slavery, flourished for several decades, and then declined following a natural disaster.

The first written reference we have found to El Palmar is its listing as a small sitio owned by D. Joaquín Hernández in 1880 . Its development as a settlement seems closely linked to the community of former slaves, most of them with the surname Quesada, who in the 1880s achieved their freedom on the Santa Rosalía plantation. During the 1895-1898 war, some of the women from Santa Rosalía moved to Cienfuegos and others were consigned to the "resettlement" camps established nearby by the Spanish general Valeriano Weyler. When these women came back after the war, they apparently found that the Spanish plantation owner Manuel Blanco had permitted new people to settle on his property. In the surviving correspondence from 1899, the administrator of Santa Ro-

55 These inferences about the names of veterans who returned to San Antón are based on the pension records of Cayetano Quesada and Zacarías González, in the APC, as well as many conversations with Cayetano Quesada's children, and a recent interview carried out by Orlando García Martínez, Rebecca Scott, and Michael Zeuske with Francisco Mena Aguila in San Antón in March 2001. 
salía grouses about these women, and reports that some have moved down to El Palmar. ${ }^{56}$

Women with the surname Quesada were soon joined by other local residents. Manuel Lago, for example, was a Spanish immigrant artisan, employed as second carpenter at Central Soledad. At an open-air dance in the foothills town of Arimao, he had met Bárbara Pérez, a handsome and literate former slave from Sebastián Pérez Galdós's Santa Teresa plantation, who now worked as a laundress in Arimao. Bárbara Pérez and Manuel Lago began to keep company, and Lago decided to build a house in El Palmar. Later he told his son Tomás that he had made the house big so that any Spanish immigrant coming to the neighborhood would have a place to stay. The house was on one side of the little arro$y o$, and the family raised ducks in the stream, as well as planting corn, boniato, squash, potatoes, onions, and other food crops. Their neighbors included other former slaves: Eduarda Quesada from Santa Rosalía, also married to a Spaniard, and Rita Iznaga, married to Bárbara Pérez's uncle Eduardo Pérez, known as Cañón. ${ }^{57}$

Edwin Atkins, the owner of Soledad plantation, was rapidly buying up properties in the neighborhood, but as late as 1906 the land to the south of Soledad was legally still an independent sitio, still under the ownership of Don Joaquin Hernández. ${ }^{58}$ Local memory attributes the expansion of the settlement at El Palmar to a Spanish shopkeeper with "a good heart," José Bravo. Bravo seems to have acquired the land around a tienda that he established at El Palmar, and to have told former slaves from Santa Rosalía that they could settle there. ${ }^{59}$ During the 1906-1909 occupation of Cuba by U.S. military forces, when Soledad served as a base for the troops, laundresses from El Palmar, including Tomás Pérez's mother, would walk the path across the arroyo to the plantation to collect the soldiers' uniforms to wash. (Indeed, one day a sergeant apparently tried to grab one of the women on her way-and another sergeant stopped the first from raping her.) ${ }^{60}$

Soledad plantation itself, extending by 1906 to over 1,798 hectares, was a looming presence, with rough barracks for seasonal laborers, a racially segmented work force, and privileged access to the power of the state. ${ }^{61}$ But in the

56 Evidence on the resettlement camps is from the recollections of Caridad Quesada, interviewed by the author in 1998 and 1999 . The 1899 correspondence of the administrator is in the private collection of Orlando García Martínez. See Constantino Pérez to Manuel García [Blanco], 20 June 1899, in these papers.

57 Tomás Pérez y Pérez, interviews with R. Scott, 1998 and 1999; Francisco Mena, interview with O. García, M. Zeuske, and R. Scott, 1 Mar. 2001.

58 See "Venta de fincas rústicas, derechos y acciones," Escritura 391, 2 Apr. 1906, f. 3248r.3317r., Protocolo José Fernández Pellón, APC.

59 José Bravo appears as the owner of record of the sitio El Palmar in a judicial notice on p. 3286 of the Gaceta Oficial de la República de Cuba, 31 Mar. 1910. The phrase "a good heart" is from Tomás Pérez y Pérez, interview with R. Scott, Mar. 1999.

60 Tomás Pérez y Pérez, interview with R. Scott, Mar. 1999.

61 On the extent and boundaries of Soledad in 1906, see "Venta de fincas rústicas, derechos y 
adjacent multiracial community of El Palmar, families could achieve some distance from the direct supervision of the plantation administration, even if they worked there, and they could multiply their employments and subsistence activities. Women's cash income and gardening labor added to family income. Women who might not be able to acquire land on their own did so through union with men who could, and vice versa.

The view from small settlements like San Antón and El Palmar gives a particular vividness to the stories of successful access to land, however informal. It may be useful, therefore, to shift the focus briefly, and look back at the prosperous sugar district of Santa Isabel de las Lajas and Cruces, asking how access to land there was opened up or constrained at different points in its history. By shifting between the close-up perspective afforded by the living memory of San Antón and El Palmar, and the sketch provided through tax records for Lajas, we can begin to circle in on the question of the fate of former slaves, and of their claims to property and to citizenship. ${ }^{62}$

\section{PROPERTY AND THE VOTE}

In 1885 , during the last full year of gradual slave emancipation, the Spanish colonial state decreed a new amillaramiento, a measuring and evaluating of properties for the purposes of taxation. The state fixed certain values for these properties, and for their agricultural products, and taxed them accordingly. The resulting list has survived for the término municipal (county) of Lajas, some 30 kilometers north of Santa Rosalía and Soledad. Though the list provides no clue concerning the civil status-former slave or otherwise-of those who held property, it does include labels indicating the perceived color of the individual property-holders. In 1885 , only eighteen of the 247 property-holders in the entire término were listed as pardo (mulatto) or moreno (black). Of these, four were categorized as pardos (among them one woman); and fourteen as morenos (among them five women). ${ }^{63}$

Here, in effect, we have the opposite effect from that of the view provided by oral history: Anyone who lacks legal title is invisible to the list-makers. Each small farm was likely to be the residence of more than the titular owner, of course, and descendants of slaves may have settled informally on or near the

acciones," Escritura 391, 2 Apr. 1906, f. 3248r.-3317r., in Protocolo José Fernández Pellón, APC. Edwin Atkins's ties to public officials are evident in the correspondence in the Atkins Family Papers, MHS.

62 Many overviews of land access by former slaves emphasize migration to towns and to Oriente, but neglect intra-regional movement. For analyses of landholding by province, based on census records, see Scott, Slave Emancipation in Cuba, ch. 11, "Land and Society"; and Pérez, Lords of the Mountain, chs. 3, 4.

63 See the order of the Captain General "para establecer Juntas Municipales para establecer en esta Isla los registros y los amillaramientos de la riqueza territorial," published in the Gaceta Oficial for 15-18 Sept. 1885. See Circular del gobernador de la provincia, Sta. Clara, 26 de septiembre de 1885, in fol. 2 r-3r, "Expediente relativo al amillaramiento de fincas urbanas y rústicas según el reglamento," inv. 1, exp. 135, leg. 2, Fondo Ayuntamiento de Lajas (FAL), APC. 
land of various kin, but the number of smallholders of color is still very small compared to the earlier slave population of Lajas, which had been 1,852 in $1875 .{ }^{64}$ It seems indisputable that in the mid-1880s legally recognized rural smallholding remained out of reach for most former slaves in Lajas. What formal landholding there was remained clustered near the towns, particularly the neighborhood of La Guinea.

Though the Spanish colonial state did almost nothing to facilitate access by former slaves to cultivable land in the 1880 s and 1890 s, it did increasingly wish to proffer a limited kind of citizenship to them, in hopes of encouraging loyalty to the colonial enterprise. Suffrage initially remained linked to taxpaying, but contained no restrictions of color or literacy. ${ }^{65}$ Gradually, the suffrage reforms instituted in Spain in the 1890s made their way to the colonies and the property requirements declined. ${ }^{66}$ Even within the sharp constraints on colonial citizenship, some men of color moved into public view in the small towns and the countryside, parallel to the increasing visibility of activists like Juan Gualberto Gómez in the capital. The electoral participation of Cubans of color in Lajas doubled between 1879 and 1881, and by 1890 the discussion of political participation by former slaves became intense. The Autonomist paper in Lajas, $E l$ Palenque, recommended that voters boycott the elections organized by the Spanish government, as a sign of disapproval of the comments of a Spanish parliamentarian who had implied that former slaves were culturally unqualified to vote. ${ }^{67}$

After anti-colonial warfare broke out again in 1895, the Spanish government found itself obliged to consider proffering a more extensive citizenship. In a series of last-minute reforms, access to the vote was opened wide. By 1898 in Lajas there were 1,426 voters, qualified simply by being male and over the age of twenty-five. Of these, some 216 were listed with no second surname, which hints at possible slave birth; and 172 of these had first surnames strongly suggestive of former slave status: Terry, Mora, Moré, Hidalgo, Madrazo, Cruz, Avilés, Palacios, Barroso, Abreu, Goytisolo, Pasalodos. ${ }^{68}$ Many of the new

${ }^{64}$ For the slave population, see R. Scott, Slave Emancipation in Cuba, p. 92.

65 See Spain, Ministerio de Ultramar, Spanish Rule in Cuba. Laws Governing the Island (New York, 1896).

66 These "reforms" were politically complex in the peninsular context. See Inés Roldán de Montaud, "Política y Elecciones en Cuba durante la Restauración," Revista de Estudios Políticos 104 (Apr.-June 1999):245-87.

67 "El Miedo a los Negros," El Palenque. Semanario Autonomista (Santa Isabel de las Lajas) 2:47 (25 May 1890), p. 1. On autonomists and the question of race and nation, see the insightful portrait of Eliseo Giberga Galí in Fernando Martínez Heredia, "El problemático nacionalismo de la primera República," Temas (Havana) 24-25 (January-June 2001):34-44 [An expanded version of the Martínez essay, in translation, is forthcoming in Cuban Studies (2003).]

${ }^{68}$ See "Lista por orden alfabético de apellidos y con numeración correlativa, de todos los vecinos mayores de veinte y cinco años que constan en el censo general de población con expresión de la edad, domicilio, profesión y si saben leer y escribir," in inv. 1 (28 enero-2 marzo 1898), exp. 161, leg. 3, FAL, APC. These surnames match those of large-scale landholders and former slaveholders. 
voters in the province of Santa Clara as a whole were identified as field laborers. ${ }^{69}$

The link between property and voting had, by 1898 , been effectively severed, and Spain's universal manhood suffrage made applicable to Cuba. The great electoral beneficiary was the Autonomist party, which won posts in the lastminute elections of March 1898. A record 41,387 men in the province of Santa Clara were eligible to vote, nearly ten times as many as had been eligible a decade earlier. ${ }^{70}$ At the national level, it was too late for an Autonomist solution. But at the local level, Autonomists were building up networks of patronage and clientele, some of which were durable enough to survive the end of the war and U.S. occupation. Moreover, some local Autonomists also had links to the armed separatists, and their influence outlived the Spanish rule within which they had maneuvered. The territory around Lajas remained for many years a stronghold of followers of the Liberal Party, many of whose leaders had fought there as rebel captains, comandantes, and generals, and others of whom had been Autonomists. ${ }^{71}$

When the war ended in the summer of 1898, the question of possible land distribution was unresolved, and a crucial moment was approaching: Would veterans and others who had retained or acquired moveable property through the vicissitudes of war be permitted to keep it? Would informal land occupation be expanded or even formalized? And would the nearly universal manhood suffrage claimed as a right by Cuban separatists - and echoed by Spain-be sustained?

The military occupation of the island by forces from the United States blocked any immediate redistribution in the form of confiscation of land belonging to those allied with the losers, as had been envisioned in some rebel documents. Moreover, the formal taking of power by a U.S. Military Government in January 1899 made the disruption of existing property titles even less likely: seizures of land would have been construed by the U.S. occupation government as an unacceptable act of "vengeance" against the Spanish. ${ }^{72}$ But Cubans were both hungry and assertive, and they pressed for land and for access to other productive resources.

In the case of Lajas, some noncombatant Cubans insisted that they be per-

69 Familiar surnames like Quesada, indicating descent from slaves on Santa Rosalía, and Sarría, generally indicating descent from slaves on Soledad or neighboring Rosario plantation, are also abundant in the 1898 electoral lists for Arimao and Caunao, the towns on either side of these plantations. See Supplemento al Boletín Oficial de la Provincia de Santa Clara, no. 63, 15 Mar. 1898, Provincia de Santa Clara.

70 See Roldán, "Política."

71 For a discussion of postwar politics in central Cuba, see Michael Zeuske, "Clientelas Regionales, Alianzas Interraciales y Poder Nacional en Torno a la 'Guerrita de Agosto' (1906)," Illes i Imperis 2 (Spring 1999): 127-56.

72 One of the rare rebel proclamations addressing the agrarian question was an 1896 rebel decree calling for the distribution of confiscated property to rebel soldiers. See Pérez, Jr., Lords of the Mountain, p. 49. 
mitted to remain on the lands which they had settled as a consequence of the "reconcentration" ordered by the Spanish General Valeriano Weyler. Ironically, the brutal policy of forced relocation had given rise to new claims of right. Thus a year after the end of the war, in July of 1899, municipal authorities were ordered to "desalojar"-evict-those who were occupying these lands. The Cubans resident on them clearly did not want to abandon their growing crops, but the government insisted that "el plazo para ocuparlos fue mientras durara la guerra y seis meses más" (the term for such occupancy was during wartime and six months after). It appears that the titular owners of the land were appealing to the mayor for help dislodging those who had remained behind. ${ }^{73}$

The summer of 1899 was a high point of pressure as insistent veterans and stubborn former pacíficos, each in their own way, made claims to horses, mules, oxen, and land. Although the United States insisted on the maintenance of a conventional property regime, even the Military Governor, General Brooke, found himself drawn into this process. To placate veterans, Brooke authorized them to formalize their claims to horses they had "acquired" during the war, by inscribing them in the local register of livestock. ${ }^{74} \mathrm{~A}$ few weeks later Ciriaco Quesada followed this procedure, but instead of claiming a horse seized during the war, he laid claim on behalf of Gregoria Quesada to a mule left back on the Santa Rosalía estate at the beginning of the war. He enlisted the help of Francisco Oliva, a former officer in the Ejército Libertador, now a sergeant in the Rural Guard, to make the claim stick. Together, they forced the nervous representative of the Spanish owner of Santa Rosalía to back down. ${ }^{75}$

Veterans of the Liberation Army not only had citizenship rights, they had what might now be called credibility - as well as horses, machetes, and a certain confidence. Moreover, they were often part of quite robust networks of friends and former comrades-at-arms, as well as networks of clientele with former officers. For those with rank, this could facilitate access to a contract as a colono (cane farmer) with a major sugar estate: The rebel General Higinio Esquerra, for example, quickly turns up in the record as a cane farmer supplying the Constancia Estate, as do other high-ranking officers. ${ }^{76}$ For former foot soldiers, it could make it easier to stay put on a small piece of land whose legal title might be debatable. A respected veteran who was also a good workman, like Cayetano Quesada, might be able to reside undisturbed on land that was listed in the property register as belonging to someone else-in this case, the Ravella heirs who held title to the lands that abutted Soledad plantation.

Implicit expectations of land and respect were joined by the veterans' quite

73 See uncatalogued document dated 21 July 1899, in FAL, APC.

${ }^{74}$ See Civil Report of Major-General John R. Brooke, U.S. Army, Military Governor, Island of Cuba (Washington, D.C.: Government Printing Office, 1900), pp. 55, 70.

75 Oliva seems to have been a shoemaker from the eastern city of Bayamo, apparently resettled in the Cienfuegos area after the war. The incident is analyzed in R. Scott, "Reclaiming Gregoria's Mule."

${ }^{76}$ See Zeuske, "Los negros hicimos la independencia," pp. 226-27. 
explicit expectations of back-pay. Indeed, the last Autonomist mayor of Lajas made the linkage clear: "The pay given to the Cuban Army will be a powerful incentive for the reconstruction of the country, because since the majority of soldiers are from the countryside, they will come back to it with resources for buying oxen and tools, and for building houses . .."77 This was perhaps an overly optimistic view. The bulk of the back-pay was a long time coming, and many soldiers ended up taking loans against it and thus losing a portion.

A sense of the magnitude of the transfer of resources can nonetheless be gained from the printed 1903 "Listas de los individuos del Ejército Libertador cuyos haberes han sido liquidados," that is, the lists of veterans who had received back-pay. A detailed sample of 816 back-pay cases also survives from Lajas in the notarial records of Domingo Valdés Losada. These convey somewhat more information about the claimants, and we can see that the bulk of the cases are from rural dwellers, with the veteran's occupation generally listed as either agricultor (farmer) or simply campo (countryside). Some of the veterans came from other regions, but the great majority (about 750) were from the Cienfuegos area. The total purchasing power of their haberes (back-pay) must have been quite significant: each foot soldier received around 400 to 900 pesos, depending on the length of his term of service. A sergeant could receive from 2,000 to $2,500 . .^{78}$

The records generated by appeals for back-pay stop just short of the point on which we would like to have detailed information: how did the successful claimants spend their money? There is no reason for the notarial records to tell. Strong circumstantial evidence, however, suggests that some veterans did indeed buy land. Recent research has shown that Esteban Montejo, immortalized as the runaway slave and rebel soldier in the life history composed by Miguel Barnet, also left substantial traces in the local archives. ${ }^{79} \mathrm{~A} 1904$ notarial record formalizes a loan of 106 pesos to Montejo from a Spanish merchant, through the assistance of a former rebel officer, Eduardo Guzmán y Macias. Then Mon-

77 Nicanor Crespo, Alcalde de Lajas al Sr. Gobernador de Santa Clara, 28 de Febrero de 1899, in Libro que contiene informes, relaciones y correspondencia sobre las memorias de la situación económica y otros particulares de Santa Clara, tomo I, f. 26/4r.-v., Secretaría de Estado y Gobernación (20 de Febrero de 1899 a 15 de Noviembre de 1900), ANC.

78 These cases are held in the notarial records of the provincial archives of Santa Clara and of Cienfuegos, and are analyzed in detail by Michael Zeuske, in "Lux Veritatis, Vita Memoriae, Magistra Vitae: 16 Vidas y la Historia de Cuba," an essay presented to the conference, "Sociedad, cultura, y vida cotidiana en Cuba, 1878-1917," held at the Centro Juan Marinello in June of 2000, and published in Josef Opatrny and Consuelo Naranjo Orovia, eds., Visitando la isla. Temas de historia de Cuba (Madrid and Frankfurt am Main: Iberoamericana-Vervuert, Cuadernos AHILA, 9, 2002), pp.161-90.

79 See Miguel Barnet, Biografía de un cimarrón (Havana: Institute of Ethnology and Folklore, 1966); Michael Zeuske, "The Cimarron in the Archives: A Re-reading of Miguel Barnet's Biography of Esteban Montejo," New West Indian Guide/ Nieuwe West-Indische Gids [NWIG] (Leiden) 71 (1997):265-79; Zeuske, "El 'Cimarrón' y las consecuencias de la guerra del 95. Un repaso de la biografia de Esteban Montejo," Revista de Indias 58 (1998):65-84; and Zeuske, "Novedades de Esteban Montejo," Revista de Indias 59 (1999):521-25. 
tejo appears twice more in 1904 , again taking small loans. The total borrowed is 430 pesos, against the 982 pesos due him once the back-pay was actually distributed. What catches the eye in this case is his occupational denomination: agricultor, farmer, strongly suggesting that somewhere along the line he became a smallholder, either as an owner or renter. ${ }^{80}$

For veterans who returned from the war determined to do something more than cut and lift cane for uncertain wages, loans against the promised back-pay were the first step toward the acquisition of subsistence plots or cane land. Veterans could also combine earnings and kin ties: It was through his wife's family, for example, that Rafael Iznaga, a veteran who was the son of slave parents, was able to settle on a small plot of land alongside the Arimao River. This sitio was in La Güira, on a hilltop marked by two mango trees. ${ }^{81}$ A pathway led straight down to San Antón, where his comrade-in-arms Cayetano Quesada had settled.

The family of a third veteran of their unit, Trino Tellería, recalls that men used to ride from one farm to another to gather to talk about the war. Trino Tellería himself, a man of color, rented a cane farm in Camarones, kept cattle (for which he registered the brand 'TT'), and later settled with some of his children in a house in Cumanayagua. His son recalls that Trino Tellería thought he was buying the house on installments, but later discovered that the seller had registered the payments as rent-thus enabling him to evict the family at will, which he did (see Photograph 2). ${ }^{82}$

Despite all the difficulties former slaves faced in gaining a foothold on the land, an inquiry that builds on oral history and microhistory turns up abundant evidence of settlement, more than appears in aggregate sources based on tax lists and census records. It is not difficult to see why this might be. Tax lists recognize only legal title to land, though informal access could be just as important to survival. Censuses tend to go household by household, and thus may agglomerate plots planted by different family members, causing the subsequent historian to underestimate the proportion of the working-age population that had access to land. Pension requests filed on the grounds of incapacity to work required an attestation that the veteran was not a property owner. A search of the property register would be carried out, and the family had no interest in calling attention to any land they might have access to through other than formal tenure. Thus only as we locate sources that convey informal access can we get a full sense of the patchwork of plantings that fended off hunger and earned ready cash. By juxtaposing oral history with documentary and cartographic evidence, one can identify particular neighborhoods, and then further interviews,

\footnotetext{
80 See "Débito y obligación," Escritura No. 437, 16 Apr. 1904, f. 1304r.-1305v., Protocolo Domingo Valdés Losada, APC; and Zeuske, "The Cimarron in the Archives."

81 Marcelino Iznaga, Sergio Arrau y García, and Arturo Iznaga, interviews with Rebecca Scott, June and Nov., 1999.

82 Fermín Tellería, interviews with R. Scott, Nov., 1999. See also the pension request filed by Nazaria Tellería in 1937, in leg. 499, Juzgado de Primera Instancia de Cienfuegos, APC.
} 
along with a combing of the notarial and judicial records, can yield some of the necessary confirmation.

As we look closely at individual communities, the modalities of access to land multiply and subdivide, encompassing plain squatting along with claims that may have carried some form of customary tenure. According to the Spanish civil code that remained in force in early republican Cuba, possession without title would give a right to dominio only under very special circumstances. ${ }^{83}$ It nonetheless appears that informal rights gained as veterans in the fight for national independence sometimes ratified claims made with only a modest legal basis in the first instance. Cash resources could complement such acquisitions: the land in the foothills town of La Sierra that Gregoria Quesada bought for 200 pesos might be worked by a mule Ciriaco Quesada claimed with his veteran's credibility. ${ }^{84}$

Former slaves and their descendants, accustomed to making do with limited resources, and to combining knowledge from various sources, made use of even the most fragile mechanisms of access to land in order to achieve some degree of food security through the production of cultivos menores. Their holdings were often so small, and so precarious, that they passed unrecorded in the surviving written documentation. Some remain visible on the land, however, like Rafael Iznaga's farm in La Güira, where a tall mango tree that once stood alongside a bohio now stands alone.

The memory of planting for oneself also emerges as part of personal stories, as when Tomás Pérez y Pérez recalls Francisca Quesada, a former slave on Santa Rosalía, as the woman who died "sembrando tomates," planting tomatoes. One morning when Tomás rode by on horseback, he greeted her as she was working in her garden. In the way of the elderly, she thanked him but wondered aloud whether she would live long enough to eat the tomatoes that the plants would yield. When he returned down the road to Rosario that evening, Francisca Quesada was dead from a heart attack. ${ }^{85}$ We very much doubt that any written record will show Francisca Quesada as the holder of property; but plant she did.

Precarious tenancy on a small piece of land not only helped to assure former slaves' subsistence, it could also strengthen claims to respect in the context of an expanded citizenship. The Cuban Constitution of 1901 eliminated the literacy and property limits on the franchise that the U.S. occupiers had imposed for the 1900 elections. Thus once Cuba became a republic in 1902 one needed only to establish residency, not taxpaying or property ownership, in order to

83 We thank Richard Turits for his observations on the phenomenon of prescripción, which apparently did permit effective claims by squatters in the haciendas comuneras of the Dominican Republic.

${ }^{84}$ On this land purchase, see "Venta de fincas rústica por la Sra Doña Lutgarda Daz Nodal viuda de Rosés a la morena Da. Gregoria Quesada," Escritura 617, 23 Oct. 1897, f. 3504r.-3507r., Protocolo Verdaguer, APC; and Scott, "Reclaiming Gregoria's Mule."

85 Interview by Rebecca Scott with Tomás Pérez y Pérez, 1998. 
vote in a given municipality. In the 1907 lists of electors Cayetano Quesada, black, age twenty-seven, appears as a voter in the Barrio de Guaos, along with thirteen other men with the single surname Quesada, including Ciriaco Quesada. $^{86}$

In the electoral list, Cayetano Quesada was recorded as an agricultor (farmer) and his neighbor Ciriaco Quesada as a labrador (fieldworker). In practice, the blending of roles between farmer and wage laborer was intricate. Men and women moved back and forth between paid work on the estate, on the one hand, and subsistence and market production, on the other. This movement could be seasonal, or weekly, or even daily, and would vary among different members of the family. At times the distinction nearly vanished, as in the case of task work such as that of a desmochador de palmiche who climbed palm trees to bring down the fruits used for fodder, and was paid by the cluster. It is unlikely that the ownership of the trees themselves was the crucial factor here, but rather the possession of the courage and skill to climb them. To the end of his days, Cayetano Quesada was known as the premier desmochador in his neighborhood.

The line between town and country, too, tends to blur when we look at it closely. Bárbara Pérez moved after emancipation to the town of Arimao, then lived with Manuel Lago in El Palmar, then on her son's colonia on Rosario, adjacent to Soledad. She also spent time in the city of Cienfuegos when she could, in search of sociability and cultura. (She was an avid reader.) The veteran Rafael Iznaga left the Soledad plantation for the hamlet of La Güira, but periodically worked for wages, and eventually moved to the town of Caunao. Trino Tellería made his way south from the town of Camarones working on various farms along the way, and ended up in Cumanayagua. Cayetano Quesada, apparently modest in his manner, lived all his life on the sitio in San Antón, but went down once a month to the city of Cienfuegos to collect his pension check. $^{87}$

In his quest for food security and a degree of autonomy, Cayetano Quesada had to tread a fine line: he needed employment from Soledad, where he worked on the Colonia Belmonte, but the continued expansion of the Soledad cane lands threatened his control over the sitio that was his base of operations. In that sense, he was a classic tenant-at-will, with fewer rights than a medieval copyholder, allowed to remain on the land in order to be available for employment

${ }^{86}$ Marial Iglesias recently located a set of Cienfuegos electoral lists from 1907 in the Archivo Nacional de Cuba, and passed the reference to us, enabling us to consult these extraordinarily detailed nominal records. See "Lista Electoral. Municipio de Cienfuegos. Provincia de Santa Clara. Censo de Septiembre 30 de 1907," in Exp. 14476, leg. 261, Fondo Secretaría de Estado y Gobernación, ANC.

87 Each of these narratives was recalled by a descendant in interviews with Rebecca Scott: Tomás Pérez (1998 and 1999) on Bárbara Pérez; Marcelino Iznaga Suaréz Román (1999 and 2000) on his uncle Rafael Iznaga; Fermín Tellería (1999) on his father Trino Tellería; and Ramona, Humberto, Francisco and Gerardo Quesada $(1998,1999,2000,2001)$ on their father Cayetano. 
in the cane fields. But to his neighbors, he was a veteran and a landholder, someone whose claim to the land was to be respected.

Recently we spoke with one of the former neighbors of Cayetano Quesada, Francisco Mena Aguila, age eighty-seven. Mena, a Cuban apparently of Spanish or Canary Island ancestry, explained that he had entered work in the Soledad mill in 1932, as a teenager. After a difficulty of some unspecified kind in El Palmar, he was told by the administrator to settle in San Antón on a plot alongside the land on which Cayetano Quesada lived. Mena put his animals to pasture in a far corner. Two years later the administrator told him he could stay there, and fence in the land where his animals were. Francisco Mena recalls responding, "You are wrong. That is land I borrowed from Cayetano." Years later, Mena explained his reasoning by invoking his neighbor's service in the Liberation Army in 1895-1898: "Cayetano had gone to the monte; they should never have taken an inch of land from him." 88

\section{EPILOGUE}

Settled on a sitio without title, but with a measure of respect, the Quesada family could eat and its members could seek wage work with somewhat less desperation. We do not know whether or how the male Quesadas cast their ballots, but in the eyes of the new Cuban state they were legally full citizens. As a practical matter, the plantation pushed its cane fields closer and closer along the edges of the Quesadas' sitio, while the family struggled to sustain their hold on the center. Members of the community like Francisco Mena nonetheless viewed Cayetano Quesada's claim based on possession as both binding on his neighbors, and superior to the claim asserted by the plantation administrator. It was, moreover, a claim that could be inherited.

By the time the 1957-1959 Cuban Revolution took hold, Cayetano Quesada had passed away. But the sitio was still there, diminished in size but occupied by his sons, his daughter Ramona, and her husband Evelio Castillo Ceballo. Dominio over much of the land in San Antón soon shifted from the Soledad Sugar Company to a new revolutionary cane cooperative, and a cadastral survey prepared by the revolutionary government in 1960 listed many of the residents as undocumented tenants, precaristas. ${ }^{89}$ Another forty years have now passed, and Cayetano Quesada's kin still cultivate the land, selling corn to the state purchasing agency at ruinously low prices. Alongside the corn, Humberto Quesada makes sure to plant some of everything — plátano (plantain), malanga, boniato (sweet potato), tomatoes, sugar cane, and quimbombó (okra). He explains simply that even if he does not live to see the harvest, someone else will (see Photograph 3). The fragile hold on the land established by Cayetano

\footnotetext{
${ }^{88}$ Mena's phrase was, “no deberían de haberle cogido ni una pulgada de tierra." Interview by Orlando García, Rebecca Scott, and Michael Zeuske, with Francisco Mena Aguila, Mar. 2001.

89 See, for example, file 2109 of the Cienfuegos records of the Investigación Preliminar, Avance Catastral, Propiedad Rústica, Instituto Cubano de Cartografía y Catastro, APC.
} 
Quesada and his descendants has now lasted more than a century. The sitio once again helps meet subsistence needs in a period of scarcity, as the set of categorical imperatives concerning property that are held to be self-evident by the state blur and dim at the edges and in the interstices of the world of cane.

The microhistory of the Cienfuegos countryside brings into somewhat clearer focus the links between property and citizenship, which turn out to be quite complex and reciprocal. Customary property rights in pigs could enable a slave to make the crucial first step into freedom. With freedom came access to wages and to the juridical institution of the notary, which in turn made it possible for some former slaves to register in writing the formal purchase of a small house lot. Returning veterans of the 1895-1898 independence war then used their standing as founders of the emergent Cuban state to make informal claims to horses and sometimes to burned-over land, along with back-pay and pensions. By 1901, when the Constitution was being drafted for the first Republic, male former slaves, along with their descendants and other neighbors, had established a robust and undeniable claim to full voting citizenship. These fragile landholdings and formal political rights would prove unequal to the task of assuring economic security, much less prosperity, to former slaves and their kin. But they helped create the conditions in which rural Cubans' aspirations toward such security and prosperity would figure centrally in the politics of twentiethcentury Cuba. 


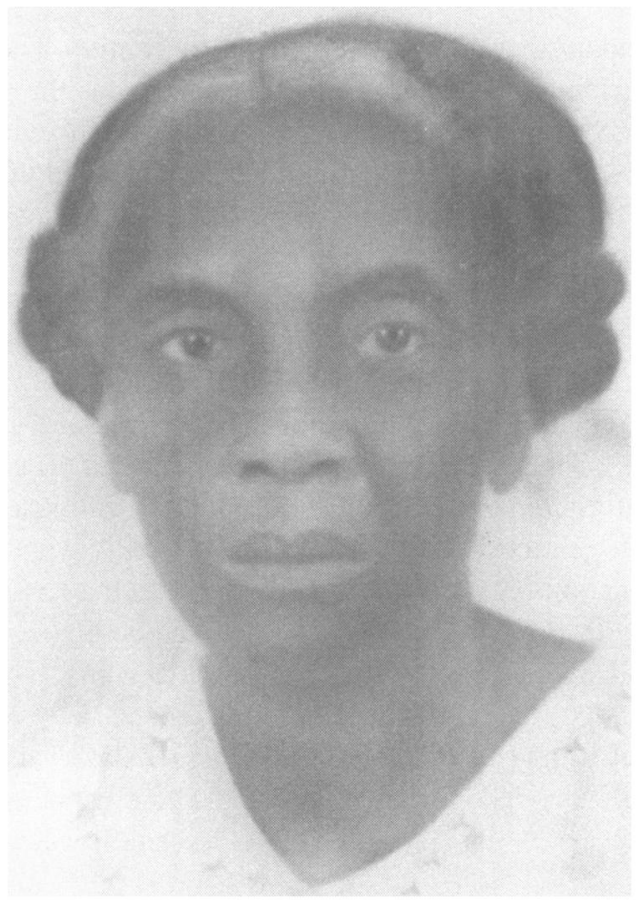

Photograph 1. Bárbara Pérez, who worked as a slave on the Santa Teresa Plantation and later settled in the hamlet of El Palmar. Photo courtesy of Olga Pérez Ribeiro. 


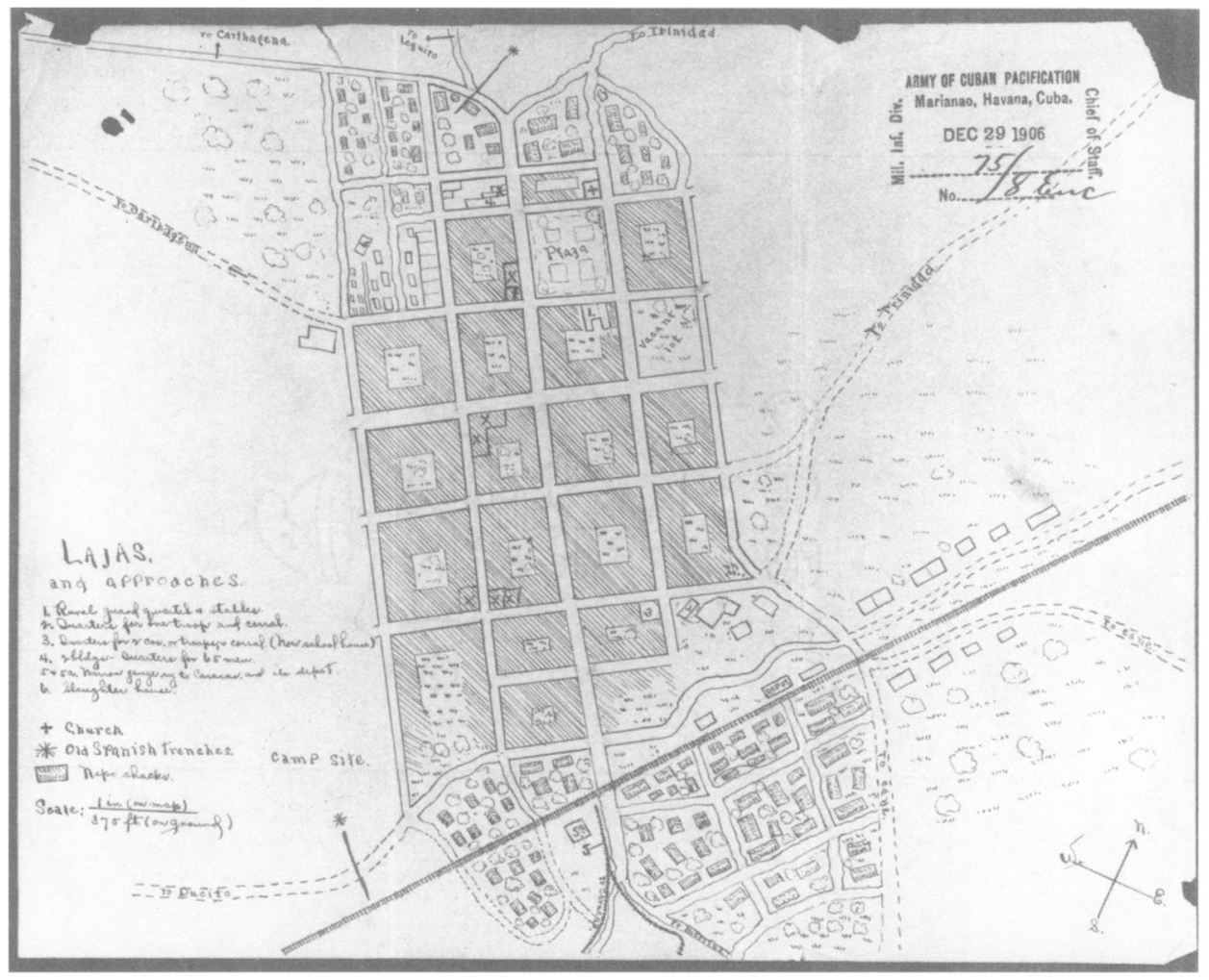

MAP 2. The town of Lajas and environs, around 1907, as sketched for the U.S. Military. The neighborhood of La Guinea is visible at the bottom, its buildings labeled "Negro Shacks." From Item 8, File 75, Entry 1008, General Correspondence, Military Information Division. U.S. Army of Cuban Pacification, RG 395, U.S. National Archives. 


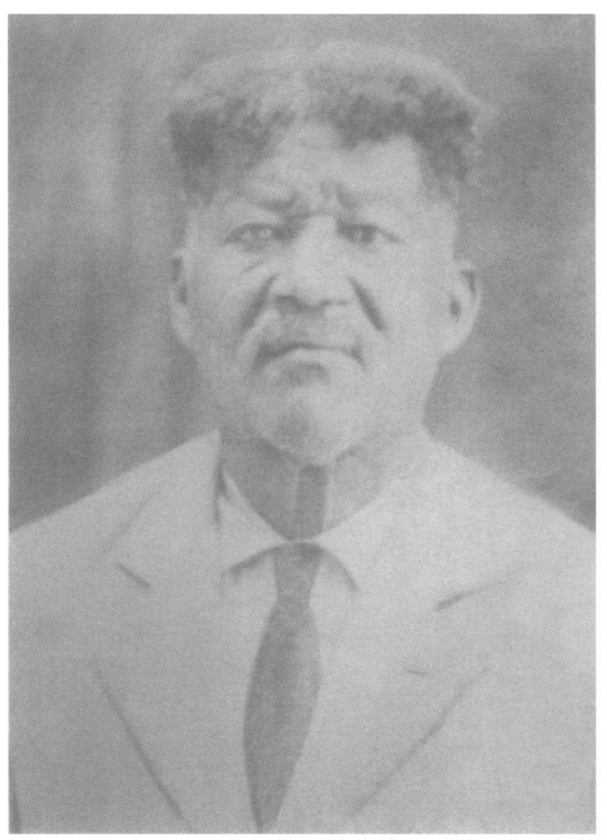

Photograph 2. Trino Tellería, a veteran of the 1895-1898 Liberation Army, worked initially as a cane farmer in Camarones. then settled in the foothills town of Cumanayagua. Photo courtesy of Fermín Tellería. 


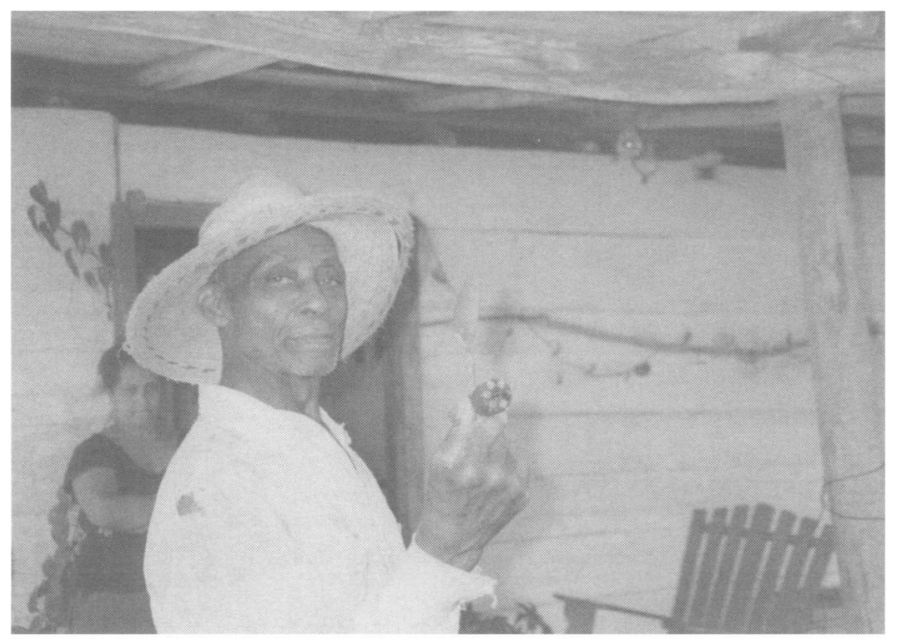

PhotograPh 3. Humberto Quesada, son of Cayetano Quesada, showing artifacts uncovered while cultivating the land that belonged to his father. Photo by Rebecca Scott. 